\title{
THE PARASITIC DINOFLAGELLATES OF MARINE CRUSTACEANS
}

\author{
Jeffrey $D$. Shields \\ Chesapeake Bay National Estuarine Research Reserves in Virginia, \\ Virginia Institute of Marine Science, The College of William and Mary, \\ Gloucester Point, VA, 23062, USA
}

\begin{abstract}
Parasitic dinoflagellates have recently emerged as significant disease agents of commercially important crustaceans. For example, epizootics of Hematodinium havc scriously affected certain crab and lobster fisheries. The parasitic dinoflagellates of crustaceans are, however, relatively unknown. Marine crustaceans are parasitized by two orders of dinoflagellates: the Blastodinida and the Syndinida. Crustaceans are also parasitized by the Paradinida and the Ellobiopsidae, taxa that have close historical ties and possible taxonomic affinities with the dinoflagellates. The taxonomy and life history patterns of the different parasitic species are largely dictated by their host-parasite relationships. For example, sporulation in the blastodinids occurs internally but is completed externally with the expulsion of spores via the anus of the host. The egg-parasitic chytriodinids sporulate externally after destroying their host egg. The tissue-dwelling syndinids have plasmodia that sporulate internally and generally kill their hosts upon the expulsion of the dinospores. Unfortunately, complete life cycles have not been elucidated for any of the parasitic forms, hence characteristics of the life cycles must be applied cautiously to the systematics of the taxa. For example, gamogony and the presence of resting cysts are only known from a few species; they probably occur in most species. Further work on the life cycles of the parasitic dinoflagcllates of crustaceans should concentrate on establishing the life cycles of representative species from each order or family. Parasitic dinoflagellates infect copepods, amphipods, mysids, euphausiids, and decapods. Their pathogenicity varies with their invasiveness in the host. The gut-dwelling blastodinids are relatively benign, while the chytriodinids kill their host egg. Members of the pervasive Syndinida and Paradinida are overtly pathogenic and insidiously ramify throughout the hemal sinuses and organs of their hosts. Members of the Ellobiopsidae vary from the commensal Ellobiocystis to the overtly parasitic Thalassomyces. Host castration and feminization are common pathologic results of infection by these parasites. The severity of the castration is dependent upon the invasiveness of the parasitic species and the duration of the infection, while the degree of feminization is related to the stage at which the host acquires the infection. Most of the parasitic dinoflagellates occur in epizootics in their host populations. Recent epizootics of Hematodinium spp. have had severe effects on crustacean fisheries in Alaska, Virginia, and Scotland, and may potentially result in changes to the benthic communities of the hosts. The epizootics are often associated with host-parasitc systems that occur in regions with unique hydrological features, such as fjords or poorly draining estuaries with shallow sills. These regions are ideal for the application of a "landscape" ecology approach that could lead to a better understanding of the epizootiology of parasitic dinoflagellates and other marine pathogens.
\end{abstract}

Keywords. Epizootiology, Life cycle, Taxonomy, Pathology, Actinodinium, Atelodinium, Blastodinium, Chytriodinium, Dissodinium, Ellobiocystis, Ellobiopsis, Hematodinium, Paradinium, Parallobiopsis, Rhizellobiopsis, Schizochytriodinium, Syltodinium, Syndinium, Thalassomyces, Trypanodinium

\section{INTRODUCTION}

Dinoflagellates are often thought of as freeliving, autotrophic protistans that live in pelagic or neritic surface waters. There are, however, many heterotrophic and parasitic forms. The parasitic dinoflagellates infect myriad marine life including but not limited to algae, protozoans, crustaceans, annelids, molluscs, salps, tunicates, rotifers, and fishes (1-3). Of the over 2,000 recognized species of dinoflagellates, approximately 140 are parasites of other organisms (4). Unfortunately, the parasitic forms have received much less attention than their free-living counterparts. This may be due to the difficulty in obtaining the planktonic hosts, the problems in culturing the parasitic forms, and, perhaps, the result of an inadequate recognition of the importance of these parasites to the population biology 
of their hosts. The parasitic species arc underrepresented; there are, without a doubt, many more to be found and described.

The parasitic dinoflagellates are unlike freeliving forms in that they lack the morphological, cytological, and biochemical features associated with a free-swimming existence (i.e. pustules, sulcus, girdle, flagella, and the cytopharyngeal funnel) $(1,2,5,6)$. For example, the syndinids, which parasitize the protistan radiolarians and copepods, have a plasmodial trophocyte or trophont that lacks most of the distinguishing features of the class. The trophocytes can be very difficult to diagnose correctly. Indeed, it was primarily on the basis of their nuclear morphology and karyokinesis that Chatton (7) determined the taxonomic affiliation of the Syndinida and the Blastodinida within the Pyrrhophyta (=Dinophyta).

Here, I review the biology and epizootiology of the parasitic dinoflagellates of marine crustaceans. The taxonomy of the different taxa is briefly summarizcd and aspects of their life cycles, pathology, and epizootiology are presented. Included in the review are two protistan taxa of unknown affinities, the Paradinida and the Ellobiopsidae. Their inclusion is warranted for comparative purposes and to illustrate the unresolved questions on their affinities to the dinoflagellates.

Since dinoflagellates have been considered as either plants or animals, the taxonomy of the parasitic forms has been in a state of flux (8). Sournia et al. (9) compared the descriptions of dinoflagellates to the rules of the Zoological Code of Nomenclature and those of the Botanical Code of Nomenclature. They declared several species nomen nudum because of the lack of published figures or the absence of proper descriptions that are required in the codes. I have accepted their emendations.

There are currently two orders that contain the known parasites of crustaceans (Table 1). Two families are in the Blastodinida, and one, possibly two, families are in the Syndinida. In addition, the Paradinida are represented by one genus, and the Ellobiopsidae by five genera. Thus, there are at least 25 recognized species and one subspecies of dinoflagellates that are parasitic in crustaceans, with an additional three species in the Paradinida, and at least 17 species in the Ellobiopsidae.

The parasitic dinoflagellates of marine Crustacea inhabit the eggs, stomach, soft tissues and the hemal sinuses of their hosts. In the past, attention was focused on their taxonomy, nuclear organization and division, and host-parasite relationships (e.g. 1,2). More recent work has documented the ultrastruc- tural similarities and differences of the parasitic forms with the free-living forms (e.g. 6,10). With the advent of major epizootics of Hematodinium sp. on commercially important crabs and lobsters $(11,12)$, and the recognized importance of outbreaks of Syndinium and Blastodinium spp. on copepod populations $(13,14)$, attention has shifted to the economic and ecological impacts of these parasites on their host populations. These epizootics have caused significant financial losses to the afflicted commercial fisheries, and as a result, more attention has been focused on these little known parasites.

\section{BLASTODINIDA}

\section{Blastodinidae}

Taxonomy. Members of the genus Blastodinium live as parasites in the stomachs of copepods. There are 12 recognized species and one subspecies in the genus (Table 1). Little taxonomic work has occurred in the genus since Sewell (15) described B. apsteini and $B$. chattoni in copepods from the Arabian Sea. The type species $B$. pruvoti was originally described from Clausocalanus arcuicornis, but it has since been found in several different hosts $(1,76)$. The subspecies $B$. contortum hyalinum was elevated to species status by Chatton (77). Sewell (15), however, recognized that there are probably several undescribed species in the B. hyalinum complex. Related species have been described from a large number of copepod hosts (Table 1). The parasite Schizodinium sparsum was declared nomen nudum after it was shown to be a stage in the life cycle of B. mangini (25).

Several taxonomic characters can be used to distinguish between species of Blastodinium. An unusual distinction is whether the species are solitary (e.g. B. contortum) or gregarious (e.g. B. pruvoti) in their respective hosts (1). Gregarious forms have a mode of three individuals per host, but as many as 25 parasites can occur in a single host. Other important taxonomic characters are the presence and location of the hilum (an area of the trophocyte not surrounded by the sporocyst and that borders the cuticle), the occurrence of schizogony, the presence and development of a helicoidal crest that may or may not possess spinules, and the general facies of the parasite. The number of sporocysts (the divisions of the sporogonal daughter cell) produced by each trophocyte is also a taxonomic character. Interestingly, the number of divisions and their blastula-like appearance led Chatton (78) to refer to the parasites as having mono-, di-, tri-, or polyblastic stages of sporogony. 
Table 1. Recognized spccics of dinoflagellates and affiliated taxa that parasitize crustaceans and their respective host species

\begin{tabular}{l}
\hline Parasite \\
\hline BLASTODINIDA \\
Blastodinidae \\
\hline $\begin{array}{l}\text { Blastodinium Chatton, } 1906 \\
\text { B. apsteini Sewell, } 1951\end{array}$ \\
B. chattoni Sewell, 1951
\end{tabular}

B. contortum Chatton, 1908

Clausocalanus arcuicornis (Dana), C, furcatus (Brady), Paracalanus 15 aculeatus Giesbrecht

Clausocalanus arcuicornis (Dana), C. furcatus (Brady), Nannocalanus minor (Claus), Paracalanus aculeatus Giesbrecht, $P$. denudatus Sewell, $P$. parvus (Claus), Cosmocalanus (=Undinula) darwini (Lubbock)

B. contortum Chatton, 1908

Acartia clausi Giesbrecht, Acrocalanus gracilis Giesbrecht, Calocalanus styliremis Giesbrecht, Clausocalanus arcuicornis Dana, Clausocalanus furcatus (Brady), Eucalanus pileatus Giesbrecht, Eucheata wolfendeni Scott, Nannocalanus minor (Claus), Paracalanus aculeatus Giesbrecht, $P$. denudalus Sewell, $P$. parvus (Claus), Cosmocalanus darwini (Lubbock)

B. crassum Chatton, 1908

Paracalanus parvus (Claus), Calocalanus styliremis Giesbrecht, Clausocalanus arcuicornis (Dana), C. furcatus (Brady)

B. elongatum Chatton, 1912

Scolecithrix bradyi Giesbrecht

1,15

Acartia clausi Giesbrecht, Calanus finmarchicus, (Gunnerus), Centropages typicus Kröyer, Clausocalanus arcuicornis (Dana), Paracalanus aculeatus Giesbrecht, $P$. denudatus Sewell, Paracalanus parvus (Claus), Pseudocalanus elongatus (Boeck), Scolecithrix bradyi Giesbrecht

B. inornatum Chatton, 1920

Clausocalanus arcuicornis (Dana), C. furcatus (Brady), Paracalanus 1, 15 parvus (Claus), P. aculeatus Giesbrecht

B. mangini Chatton, 1908

Corycella gibbulus Giesbrecht, $C$. rostrata Farran, Oncaea conifera 1, 15 Giesbrecht, $O$. media Giesbrecht, $O$. venusta Philippi

B. mangini oncae Chatton, 1912

B. navicula Chatton, 1912

Oncaea media Giesbrecht, $O$. minuta Giesbrecht, Corycella rostratus Claus

Corycella venustus Dana

Corycaeus crassiusculus Dana, C. gibbulus Giesbrecht, C. speciosus 1, 15 Dana, Oithona conifera Giesbrecht, $O$. helgolandica Claus, $O$. media Giesbrecht, $O$. nana Giesbrecht, $O$. plumifera Baird, $O$. venusta Philippi

B. pruvoti Chatton, 1906

Clausocalanus arcuicornis (Dana), C. furcatus (Brady), Nannocalanus minor (Claus), Paracalanus parvus (Claus)

B. spinulosum Chatton, 1908 Acrocalanus gracilis Giesbrecht, Clausocalanus arcuicornis (Dana), C. furcatus (Brady), C. farrani Sewell, Paracalanus aculeatus Giesbrecht, $P$. denudatus Sewell, $P$. parvus (Claus)

\begin{abstract}
Blastodinium sp.
Blastodinium sp.

Blastodinium sp.
\end{abstract}

Temora stylifera Dana

Eucalanus subtenuis Giesbrecht

Clausocalanus furcatus (Brady), C. lividus, Corycaeus flaccus Giesbrecht, C. typicus (Kröyer), rarely in Centropages typicus Kröyer, Euaetidius giesbrechti (Cleve), Pleuromamma gracilis (Claus), Nannocalanus minor (Claus)

\section{Chytrodinidae}

Chytriodinium Chatton, 1912
C. affine (Dogiel, 1906)
C. roseum (Dogiel, 1906)
C. parasiticum (Dogiel, 1906)

eggs of copepods

eggs of Meganyctiphanes novegica (Sars)

eggs of penaeid (?) shrimps
18,19

19

19 
Table 1. (continued)

\begin{tabular}{|c|c|}
\hline Parasite & \\
\hline \multirow{2}{*}{\multicolumn{2}{|c|}{$\begin{array}{l}\text { Dissodinium Klebs in Pascher, } \\
1916 \\
\text { D. pseudocalani } \\
\quad \text { (Gönnert, 1936) }\end{array}$}} \\
\hline & \\
\hline $\begin{array}{l}\text { D. pseudolu } \\
\text { Elbrächte }\end{array}$ & $\begin{array}{l}\text { la Swift in } \\
\text { Drebes, } 1978\end{array}$ \\
\hline $\begin{array}{l}\text { Schizochytriod } \\
\text { Elbrächte }\end{array}$ & ium calani \\
\hline Syltodinium li & Drebes, 1988 \\
\hline $\begin{array}{l}\text { SYNDINIDA } \\
\text { Syndinidae }\end{array}$ & \\
\hline
\end{tabular}

Actinodinium apsteini Chatton \& Hovasse, 1938

eggs of Pseudocalanus elongatus (Boeck)

eggs of Temora longicornis (Müller), Acartia sp., cysts of rotifers 21

eggs of Calanus glacialis Jaschnov, C. hyperboreus Kröyer

eggs of Temora longicornis (Müller), Acartia sp., Pseudocalanus elongatus (Boeck)

Trypanodinium ovicola Chatton, 1912

Syndinium Chatton, 1912

S. corycaei Chatton in Grasse, 1952

S. gammari Manier, Fize \& Grizel, 1971

S. turbo Chatton, 1912

Syndinium sp.

Syndinium sp.

?Syndinium sp?

Hematodinium Chatton \& Poisson, 1931

H. perezi Chatton \& Poisson, 1931

$H$. cf. perezi

H. cf. perezi

H. "australis"

H. cf. "australis"

Hematodinium sp. Hematodinium sp. ?Hematodinium sp?

?Hematodinium sp?

\section{PARADINIDA}

Paradinium Chatton, 1910

P. caulleryi Chatton \& Soyer, 1973
Acartia clausi Giesbrecht

eggs of Oithona spp., Clytemnestra spp., Oncaea media Giesbrecht 1

Corycaeus geisbrechti Dahl (=C. venustus Dana)

Gammarus locusta (L.)

Paracalanus parvus (Claus)

Calanus finmarchicus (Gunnerus), Clausocalanus arcuicornis

(Dana), Oithona helgolandica Claus

Eucalanus pseudattenuatus Sewell, Euchirella pulchra (Lubbock), Oncaea venusta typica Philippi

eggs of Pandalus borealis Kröyer

Carcinus maenus (L.), Liocarcinus depurator (L.), Platyonychus $5,25,29$, latipes Penn, Cancer pagurus (L.), Necora (Liocarcinus) puber (L.) 30

Ovalipes ocellatus (Herbst), Cancer borealis Stimpson

Callinectes sapidus Rathbun

Portunus pelagicus (L.)

33,34

Scylla serrata (Forskál), Trapezia areolata Dana, T. coerulea

34,35 (Herbst)

Chionoecetes bairdi Rathbun, C. opilio (Fabricius)

11,36

Nephrops norvegicus (L.)

Ampelisca agassizi (Judd), A. vadorum Mills, A. verrilli Mills, Byblis serrata Smith, Casco bigelowi (Blake), Harpinia propinqua Sars, Leptocheirus pinguis (Stimpson), Melita dentata (Kröyer), Monoculodes edwardsi Holmes, Protohaustorius wigleyi Bousfield, Phoxocephalus holbolli Kröyer, Rhepoxynius epistomus (Shoemaker), Unciola spp

Pandalus borealis Kröyer, $P$. platyceros Brandt

38,39

Oncaea media Giesbrecht

40

(continued) 
Table I. (continued)

\begin{tabular}{|c|c|c|}
\hline Parasite & Host species & Reference \\
\hline $\begin{array}{l}P . \text { mesnili Chatton \& Soyer, } \\
1973\end{array}$ & Oncaea conifera Giesbrecht & 40 \\
\hline P. poucheti Chatton, 1910 & $\begin{array}{l}\text { Acartia clausi Giesbrecht, Oithona helgolandica Claus, } O \text {. } \\
\text { plumifera Baird, Clausocalanus arcuicornis (Dana), Paracalanus } \\
\text { parvus (Claus), Centropages typicus Kröyer }\end{array}$ & $1,40,41$ \\
\hline \multicolumn{3}{|l|}{$\begin{array}{l}\text { ELLOBIOPSIDAE } \\
\text { Ellobiocystis Coutière, } 1911\end{array}$} \\
\hline E. caridarum Coutière, 1911 & $\begin{array}{l}\text { Acanthephyra purpurea Milne-Edwards, } \text { A. eximia } \text { Smith, } \\
\text { Antarctomysis maxima Hansen, Pasiphaea pacifica Rathbun, } \\
\text { P. semispinosa Holthuis, Sergestes spp., Systellaspis debilis } \\
\text { (Milne-Edwards) }\end{array}$ & $1,42,43$ \\
\hline E. catenatus Coutière, 1911 & Acanthephyra purpurea Milne-Edwards & 1,42 \\
\hline E. tenuis Coutière, 1911 & Pasiphaea sivado (Risso) & 1,42 \\
\hline E. tuberosus Coutière, 1911 & Acanthephyra purpurea Milne-Edwards & 1,42 \\
\hline $\begin{array}{l}\text { Ellobiopsis } \\
\quad \text { E. chattoni Caullery, } 1910\end{array}$ & $\begin{array}{l}\text { Acartia clausi Giesbrecht, Calanus helgolandica Claus, C. finmar- } \\
\text { chicus (Gunnerus), Clausocalanus arcuicornis (Dana), Ctenocalanus } \\
\text { vanus Giesbrecht, Euchaeta marina (Prestandrea), E. wolfendeni } \\
\text { Scott, Metridia longa (Lubbock), Pleuromamma gracilis (Claus), } \\
\text { P. borealis (Dahl), Pseudocalanus elongatus (Boeck), P. minutus } \\
\text { (Kröyer), Cosmocalanus (= Undinula) vulgaris (Sewell), zoeae of } \\
\text { Portunus pelagicus (L.) }\end{array}$ & $15,44-48$ \\
\hline E. elongata Steuer, 1932 & $\begin{array}{l}\text { Clausocalanus arcuicornis (Dana), Ctenocalanus vanus } \\
\text { (Giesbrecht), Cosmocalanus darwini, Euchaeta marina } \\
\text { (Prestandrea), Gaetamus antarcticus Wolfenden, G. curvicornis } \\
\text { Sars, postlarvae of Penaeopsis retacuta (Bate) }\end{array}$ & $15,49,50$ \\
\hline E. fagei Hovasse, 1951 & pelagic copepods, Clausocalanus arcuicornis (Dana) & 51 \\
\hline $\begin{array}{l}\text { Parallobiopsis coutieri Collin, } \\
1913\end{array}$ & Nebalia bipes Fabricius & 52 \\
\hline $\begin{array}{l}\text { Rhizellobiopsis eupraxiae } \\
\text { (Zachs, 1923) }\end{array}$ & polychaete: Nephthys ciliata Müller & 53 \\
\hline $\begin{array}{l}\text { Thalassomyces Niezabitowski, } \\
1913 \text { (=Staphylocystis Coutière, } \\
\text { 1911; =Amalocystis Fage, 1936) }\end{array}$ & & \\
\hline T. albatrossi Wing, 1975 & Stilomysis major Tattersall & 54 \\
\hline T. boschmai (Nouvel, 1954) & $\begin{array}{l}\text { wide range of mysids: Acanthomysis macropsis (Tattersall), } \\
\text { A. nephrophthalma Banner, A. pseudomacropsis (Tattersall), } \\
\text { Gastrosaccus lobatus Nouvel, Leptomysis gracilis (Sars), } \\
\text { Meterythrops robusta Smith, Neomysis kadiakensis Ortmann }\end{array}$ & $54-58$ \\
\hline $\begin{array}{l}\text { T. californiensis } \text { Collard, } \\
1966\end{array}$ & Pasiphaea emarginata Rathbun & 59 \\
\hline T. capillosus (Fage, 1938) & $\begin{array}{l}\text { Pasiphaea tarda Kröyer, } P \text {. pacifica Rathbun, } P \text {. multidentata } \\
\text { Esmark, } P \text {. acutifrons Bate }\end{array}$ & $\begin{array}{l}60,61 \\
54\end{array}$ \\
\hline T. fagei (Boschma, 1948) & $\begin{array}{l}\text { wide range of euphausids: Euphausia diomedeae Ortman, } \\
\text { E. distinguenda Hansen, E. frigida Hansen, E. hemigibba Hansen, } \\
E \text {. krohnii (Brandt), E. lucens Hansen, E. pacifica Hansen, } \\
\text { E. pseudogibba Ortman, E. recurva Hansen, E. sanzoi Torelli, } \\
\text { E. tenera Hansen, E. vallentini Stebbing, Meganyctiphanes norvegica } \\
\text { (Sars), Nematoscelis difficilis Hansen, Nyctiphanes australis Sars, } \\
N . \text { capensis Hansen, Pseudeuphausia latifrons (Sars), Thysanoessa } \\
\text { gregaria Sars, T. inermis (Kröyer), T. raschii (Sars) }\end{array}$ & $\begin{array}{l}43,54,57, \\
61-65\end{array}$ \\
\hline T. fasciatus (Fage, 1936) & $\begin{array}{l}\text { mysids in the genus Gnathophausia: } G . \text { zoea Willemoes-Suhm, } \\
G \text {. ingens (Dohrn), G. gracilis Willemoes-Suhm, G. gigas } \\
\text { Willemoes-Suhm }\end{array}$ & 66,67 \\
\hline
\end{tabular}


Table 1. (continued)

\begin{tabular}{|c|c|c|}
\hline Parasite & Host species & Reference \\
\hline T. marsupii Kane, 1964 & $\begin{array}{l}\text { in amphipods: Cyphocaris challengeri Stebbing, Cystisoma sp., Eu- } \\
\text { sirus leptocarpus Sars, E. longipes Boeck, Parathemisto abyssorum } \\
\text { (Boec), P. gaudichaudii (Guerin), P. gracilipes Norman, P. libellula } \\
\text { (Lichtenstein), P. pacifica Stebbing, Rhachotropis arculeata } \\
\text { (Lepechin), R. helleri Boeck, R. macropus Sars }\end{array}$ & $54,68-71$ \\
\hline $\begin{array}{l}\text { T. niezabitowski Hoenigman, } \\
1960\end{array}$ & Leptomysis megalops Zimmer & 72 \\
\hline $\begin{array}{l}\text { T. nouveli (Hoenigman, } \\
\text { 1954) }\end{array}$ & Anchialina agilis (Sars) & 73 \\
\hline $\begin{array}{l}\text { T. racemosus (Coutière, } \\
1911 \text { ) }\end{array}$ & $\begin{array}{l}\text { Acanthephyra pelagica (Risso), A. sexspinosa Kemp, Hymenodora } \\
\text { glacialis (Buchholz), Pasiphaea cristata Bate, } P \text {. tarda Kröyer }\end{array}$ & $42,43,74$ \\
\hline $\begin{array}{l}\text { T. spiczakovii Niezabitowski, } \\
1913\end{array}$ & $P$. sivado (Risso) & 75 \\
\hline $\begin{array}{l}\text { T. umbellatus (Boschma, } \\
\text { 1949) }\end{array}$ & $\begin{array}{l}\text { in oplophorid shrimps: Oplophorus gracilirostris Milne-Edwards, } \\
\text { O. grimaldii Coutière, O. novaezeelandiae de Man }\end{array}$ & $43,61,74$ \\
\hline Thalassomyces spp? & $\begin{array}{l}\text { Amphipoda: Calamorhynchus pellucidus Streets, Mysidacea: } \\
\text { Siriella clausi Sars, others under Thalassomyces boschmai }\end{array}$ & 65 \\
\hline
\end{tabular}

Life cycle. The generalized life cycle of the genus Blastodinium is given in Figure 1. Experimental attempts to transmit the parasites to uninfected hosts have been unsuccessful $(1,27)$, but portions of the life cycle have been deciphered from observations in living hosts. Chatton (1) suggested that dinospores are probably ingested by the nauplii or early copepodite stages. A single, large trophocyte develops from the ingested dinospore, and divides into a secondary trophocyte and a gonocyte. The trophocyte may undergo schizogony, but it rarely occurs in most species. The gonocyte then undergoes sporogony to form a series of primary, secondary or tertiary sporocysts. Each generation of sporocysts is enclosed in a cuticle that dehisces during sporulation $(1,15,78)$. The parasites are generally around $200-700 \mu \mathrm{m}$ long by $30-200 \mu \mathrm{m}$ in breadth, but their size varies with the size of the host species, the number of parasites present, and the size of the individual host $(1,15,27)$.

After repeated divisions of the sporocytes, sporulation takes place. Immature spores without flagella are expelled via the feces and develop into mature dinospores (1). Mature spores have a well marked transverse groove, but they may or may not have a longitudinal groove $(1,15)$. The spores are typically gymnodinoid, oval, $10-13 \mu \mathrm{m}$ in length by $8 \mu \mathrm{m}$ in breadth, and possess plastids. The dinospores encyst after 1-2 days; their fate thereafter is unknown.

General biology. The trophocytes of Blastodinium spp. possess chloroplasts that are capable of photosynthetic activity (1). Pasternak et al. (80) experimentally determined the activity and contribution of the chloroplasts to the energy budget of the parasite and its dinospores. The primary productivity to biomass ratio was $0.2-0.4$, which, while difficult to compare with other methods, was considerably lower than that for many species of dinoflagellates (81). The energy produced by photosynthesis was reported to be about $50 \%$ of the energy budget of the parasite. The drain on the host was thought to be considerable as the infected hosts died more quickly than uninfected hosts when maintained in the dark (80). The results were, however, ambiguous for hosts maintained in the light; uninfected hosts did not survive as well as infected hosts, but there was considerable variance in the experiment. Since many of the copepod hosts for Blastodinium spp. are mesopelagic, it is questionable how much the photosynthetic process actually contributes to the nutrition of the parasite.

Pathology. Infection by Blastodinium spp. results in the lack of or poor development of the gonads and oviducts of their hosts $(1,15,27)$. This parasitic castration was not, however, observed by Ianora et al. (17). Host castration probably results from the physiological drain of the parasite on the resources of the host, or perhaps because of the mechanical pressure of the parasite on vital internal organs of the host. The parasites almost completely occupy the alimentary tract and can deform its lining. Incomplete castration may arise when mature hosts become infected with the parasites. Parasitic 

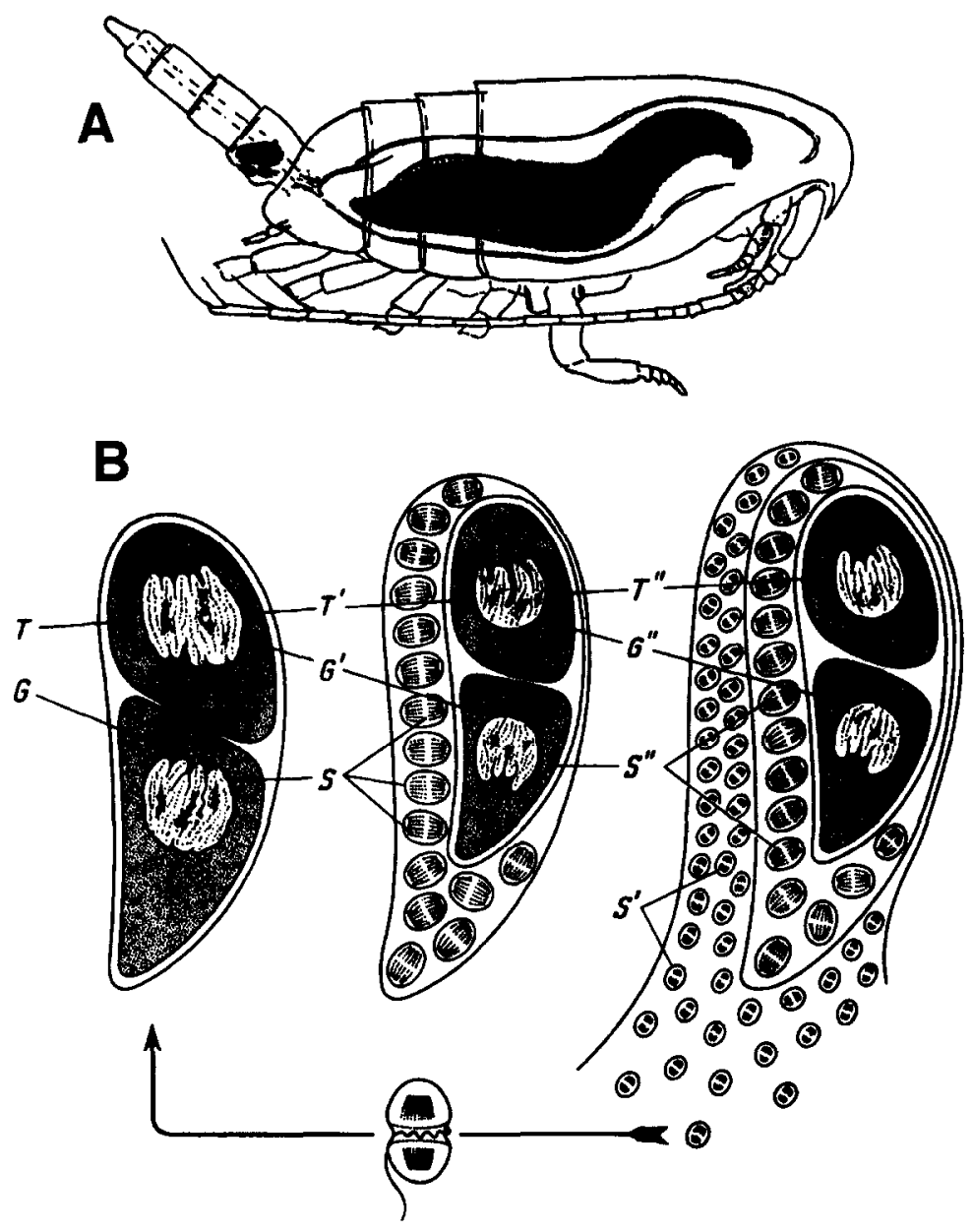

Fig. 1. Generalized life cycle of species of Blastodinium. (A) Blastodinium contortum in Clausocalanus furcatus (reprinted with permission from [15]); (B) Schematic diagram of sporogony (reprinted with permission from [79]). Key: $T, T^{\prime}, T^{\prime \prime}$, successive trophocytes; $G, G^{\prime}, G^{\prime \prime}$ successive gonocytes; $S, S^{\prime}, S^{\prime \prime}$ developing sporocytes.

castration is a common phenomenon in crustacean hosts; it may result from several different mechanisms, such as, the physical disruption of the gonads, the high energetic costs of the parasite on the host, and the interference of the parasite with the hormones that control the reproduction of the host (82).

Parasitic castration of crustaceans often results in the cessation of molting of the host or the feminization of male hosts $(82,83)$. Chatton (1) noted that the final molt of male hosts was inhibited by infection with Blastodinium spp. Ecdysis did, however, occur in other infected copepodite stages. Jepps (27) was unable to determine if molting ceased but her data indicated that possibility. Most of her infected copepods were either females or stage IV co- pepodites. Few males were infected. There was no indication of feminization of male hosts $(15,27)$. However, Cattley (84) suggested that the final molt of infected male hosts resulted in sex reversal. She may have inadvertently observed the intersex of the host which is not necessarily associated with parasitism (see Syndinium pathology). Cattley (84) also reported a higher prevalence of infection in males than in females and juveniles. Note, however, that Chatton (1), having examined and dissected thousands of copepods, never found an infected male! Similarly, Ianora et al. (17) reported finding only one infected male out of several thousand copepods.

Infection by Blastodinium does not appear to inhibit the mating of the hosts. Infected copepods bearing spermatophores are figured by Jepps (27) 
and Cattley (84). The importance of sterile matings in crustacean populations infected with parasitic castrators has only recently been identified (85). They represent a hidden cost to the host population that has not been factored into recent models of population dynamics.

Epizootiology. There appears to be a marked seasonality in the prevalence of Blastodinium infections. Chatton (1) found infected copepods primarily in the summer and fall months at Banyuls-sur-Mer, France. He noted that the prevalence of infection was very low $(<1.0 \%)$ in early spring and did not exist in winter. Sporulation of the parasite is presumably affected by decreasing temperatures (1).

Blastodinium spp. have been reported from the Mediterranean Sea, the Skagerrak, the North Sea, the Arabian Sea, the southeast Pacific Ocean, and Japan $(1,15,16,80,86,87)$. In general, the parasites have a low prevalence in their host populations (Table 2). However, epizootics of Blastodinium spp., in which more than $10 \%$ of the hosts are infected, have been reported from the North Sea, the Mediterranean Sea and the southeast Pacific Ocean $(1,80,87)$. Pasternak et al. (80) suggest that the parasites are more abundant in nutrient-poor temperate or tropical waters, hence, the higher diversity and prevalence in hosts from these regimes. Chatton (77) shows that the genus is more common and more diverse in temperate waters than in colder boreal waters. In fact, only one species, $B$. hyalinum, occurs in northern waters, and then only infrequently during summer months $(1,27,77)$. Curiously, $B$. hyalinum is the only described species that lacks chloroplasts (1); a finding that may support the hypothesis of Pasternak et al. (80).

\section{Chytriodinidae}

Taxonomy. There are four genera in the Chytriodinidae that parasitize crustaceans: Chytriodinium, Schizochytriodinium, Dissodinium, and Syltodinium. The three species of Chytriodinium live as ectoparasites on the eggs of copepods, euphausiids, and penaeid shrimps. They were first described by Dogiel (18) as members of Gymnodinium but they were later separated by Chatton (93). No new species have been described since then, but Cachon and Cachon (19) erected the family and firmly established the status of the three species. The size of the trophont and the complexity of the holdfast are the primary taxonomic characters of the species.

Schizochytriodinium calani may be closely allied to the genus Chytriodinium (22). There are two major differences that separate the genera. The major distinction is in their life cycles; $S$. calani reproduces by palisporogenesis, with sporogony occurring in detached secondary sporocysts, while Chytriodinium spp. reproduces via palintomy, with sporogony occurring in a sporocyst attached to the remains of the trophocyte $(19,22)$. In addition, S. calani lacks a conspicuous holdfast, instead it penetrates the egg coat of its host with a peduncle-like organelle.

The genus Dissodinium contains two described species, both of which are ectoparasitic on copepod eggs. The tortuous taxonomy of the genus is given by Drebes (21) and Elbrächter and Drebes (94). There are several important characters that separate the genus from Chytrodinium, enough perhaps to warrant the creation of a separate family in the Blastodinida $(21,94)$. Members of Dissodinium possess two unusual cyst stages that are not directly related to sporogony. The dinospores produce an individual cyst shortly after their liberation, and there is an apparent resting cyst that may indicate sexual reproduction (95). Sexuality in the life cycle has not been previously described for other members of the family (4). In addition, unlike Chytriodinium spp., the trophonts of $D$. pseudolunula and D. pseudocalani detach from the remains of their host egg prior to sporogenesis.

Although Syltodinium listii is also an ectoparasite of copepod eggs, its taxonomic relationship within Chytriodinium is not clear (23). The primary difference between $S$. listii and Chytriodinium spp. is that the former, like Dissodinium spp., undergoes sporogenesis in a detached state from the host (see below). Indeed, sporogenesis in S. listii occurs in a palmelloid multiplication stage that is covered with a gelatinous matrix (23). Like Schizochytriodinium calani, but different from Chytriodinium spp., $S$. listii grows a peduncle-like organelle for penetration of the eggs. It does, however, undergo palintomy as in Chytriodinium spp., but in a detached state.

Life cycles. The generalized life cycle of Chytriodinium spp. is given in Figure 2. A dinospore attacks a host egg and a stalk forms. The stalk, which is the functional hypocone, penetrates the egg of the host and grows through the chorion or egg coats (Fig. 3) (19). With C. parasiticum, the penetration of the outer coat may take as long as $\mathbf{2 4}$ hours, and may be the result of the thicker outer coat of the egg of its penaeid shrimp host. Upon reaching the embryo, the hypocone develops a holdfast-like anchor that contains a small band of hooks and the feeding apparatus or ampulla. In $C$. parasiticum, the hypocone then shortens so that the episome is brought into contact with the egg, but in the other species the smaller hypocone does not change. The parasite now appears "rivettcd onto the 
Table 2. Reported prevalences of dinoflagellates parasitizing crustaceans

\begin{tabular}{lcccc}
\hline Parasite & Prevalence & Location & Reference \\
\hline
\end{tabular}

\section{Blastodinidae}

Blastodinium hyalinum

Calanus finmarchicus

Pseudocalanus elongatus (juvs.) Pseudocalanus elongatus (fems.) Pseudocalanus elongatus (males)

B. crassum

B. mangini
B. navicula
B. spinulosum

Blastodinium sp.

Chytrodinidae

Chytriodinium spp. host eggs Paracalanus parvus (juveniles) $P$. parvus (females) $P$. parvus (males)

$P$. parvus

Corycella rostrata

Corycella venustus

Paracalanus parvus

Clausocalanus spp.

Eucalanus subtenuis

Syndinidae

Syndinium turbo

Syndinium sp.

Syndinium sp.

Syndinium sp.

Syndinium sp.

Syndinium sp.

Syndinium sp.

Syndinium sp.

Syndinium sp.

Syndinium sp.

Syndinium sp.

Hematodinium perezi

H. perezi

$H$. cf. perezi

$H$. cf. perezi

$H$. cf. perezi

$H$. cf. perezi

$H$. cf. perezi

H. cf. perezi

Hematodinium $\mathrm{sp}$ ?

Hematodinium sp?

Hematodinium sp?

H. "australis"

$\begin{array}{ll}\text { H. cf. "australis" } & \text { Trapezia aerolata } \\ \text { H. cf. "australis" } & \text { Scylla serrata } \\ & \\ \text { ?Hematodinium sp? } & \text { Pandalus platyceros } \\ & \text { Ampelisca agassizi } \\ & \text { A. vadorum } \\ & \text { A. verrilli } \\ & \text { Byblis serrata } \\ & \text { Casco bigelowi }\end{array}$

Paracalanus parvus

Calanus finmarchicus

copepods (1934)

copepods (1935)

copepods (1936)

Paracalanus parvus (juveniles)

$P$. parvus (females)

$P$. parvus (males)

P. parvus

$P$. indicus (imm. fems.)

$P$. indicus (females)

portunid hosts

Necora puber

Ovalipes ocellatus

Cancer irroratus

Ovalipes ocellatus

Cancer borealis

Callinectes sapidus

Callinectes sapidus

Chionoecetes bairdi

Chionoecetes bairdi

Nephrops norvegicus

Portunus pelagicus

$\begin{array}{cl}3.7-60 & \text { North Sea } \\ 0.3 & \text { Dogger Bank } \\ 3.7 & \text { Dogger Bank } \\ 20.5 & \text { Dogger Bank } \\ 1.2 & \text { Gulf of Naples, Italy } \\ 0.3 & \text { Gulf of Naples, Italy } \\ 0.0 & \text { Gulf of Naples, Italy } \\ 1.5 & \text { Mediterranean Sea } \\ 10.0 & \text { Banyuls-sur-Mer, France } \\ 20.0-30.0 & \text { Banyuls-sur-Mer, France } \\ 0.4 & \text { Mediterranean Sea } \\ 0.8-6.6 & \text { Mediterranean Sea } \\ 6-12 & \text { SE Pacific Ocean }\end{array}$

50 Ville-franche, France
19

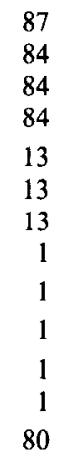

84

84

84

13

13

1

1

1

1

80
6.7 Great Barrier Reef, Australia
1.5 Moreton Bay, Australia

British Columbia

NE USA continental shelf

NE USA continental shelf

NE USA continental shelf

NE USA continental shelf

NE USA continental shelf 
Table 2. (continued)

\begin{tabular}{llrlr}
\hline Parasite & \multicolumn{1}{c}{ Host } & $\begin{array}{c}\text { Prevalence } \\
(\%)\end{array}$ & Location & Reference \\
\hline ?Hematodinium sp? & Harpinia propinqua & 18 & NE USA continental shelf & 37 \\
(continued) & 4 & NE USA continental shelf & 37 \\
& Leptocheirus pinguis & 8 & NE USA continental shelf & 37 \\
& Melita dentata & 27 & NE USA continental shelf & 37 \\
& Monoculodes edwardsi & 20 & NE USA continental shelf & 37 \\
& Protohaustorius wigleyi & 27 & NE USA continental shelf & 37 \\
& Phoxocephalus holbolli & 20 & NE USA continental shelf & 37 \\
& Rhepoxynius epistomus & 9 & NE USA continental shelf & 37
\end{tabular}

Ellobiopsidae

$\begin{array}{ll}\text { Ellobiocystis caridarum } & \text { P. pacifica } \\ \text { Ellobiopsis chattoni } & \text { Calanus finmarchius } \\ & \text { Metridia longa } \\ & \text { Undinula vulgaris } \\ & \text { U. vulgaris }\end{array}$

Thalassomyes boschmai A. pseudomacropsis Neomysis kadiakensis Neomysis kadiakensis (adults) Neomysis kadiakensis (stage IV)

T. californiensis $P$. emarginata

T. capillosus

Pasiphaea tarda

P. pacifica

T. fagei

T. marsupii
E. lucens

Thysanoessa gregaria

T. inermis

T. raschii

T. raschii

P. Libellula

P. pacifica

Cyphocaris challengeri

\begin{tabular}{clc}
$<10-84.0$ & Auke Bay, Alaska & 54 \\
0.3 & Loch Striven, Scotland & 45 \\
$5.0-22.4$ & Kachemak Bay, Alaska & 57 \\
8.3 & Bay of Bengal, India & 50 \\
26.0 & Zanzibar Channel off & \\
& Africa & 90 \\
0.2 & Auke Bay, Alaska & 54 \\
$0.8-1.2$ & Auke Bay, Alaska & 54 \\
$1.0-17.0$ & Puget Sound, Washington & 58 in 54 \\
$1.0-35.0$ & Puget Sound, Washington & 58 in 54 \\
$0.0-24.3$ & Santa Barbara, California & 59 \\
30.0 & Santa Barbara, California & Shields, \\
& & unpubl. \\
& & data \\
$13.3-20.0$ & Oslofjord, Norway & 65 \\
$5.0-40.9$ & Auke Bay, Alaska & 54 \\
$4.7-23.1$ & South Atlantic Ocean & 91 \\
$1.9-4.4$ & South Atlantic Ocean & 91 \\
$1.1-14.3$ & South Atlantic Ocean & 91 \\
$10.0-16.7$ & North Sea & 92 \\
$1.0-1.1$ & North Sea & 92 \\
13.0 & Kachemak Bay, Alaska & 57 \\
$0.2-0.7$ & Auke Bay, Alaska & 54 \\
8.3 & Auke Bay, Alaska & 54 \\
$1.0-10$ & Auke Bay, Alaska & 54 \\
\hline & &
\end{tabular}

egg envelope" (6). After penetration by the hypocone, the egg is consumed by the parasite in 1-2 hours. The parasite then undergoes sporulation via palintomy. Dinospores are produced in long chains that dissociate before they develop flagella. Dinospores possess two Mlagella, lack plastids, and are about 6-9 $\mu \mathrm{m}$ long. Chytriodinium parasiticum has been maintained in culture for short periods (19). It is not known whether it possesses a resting stage.

Schizochytriodinium calani has a life cycle of about 4 days (22). A dinospore attacks an egg and develops into a trophont. The trophont sends its peduncle-like organelle into the egg where it assimilates the developing embryo. The trophont then divides to form a primary cyst (cf. trophocyte) and a secondary cyst (sporocyst). The wall of the pri- mary cyst ruptures and releases the secondary cyst that then completes sporulation in the water column. The trophocyte remains attached to the egg and continues to feed; it sequentially produces 3-4 secondary cysts. Each secondary cyst undergoes palintomy to produce 132-264 dinospores. During sporulation, the secondary cyst wall ruptures and releases long chains of developing dinospores that separate into individual spores after a short time. Dinospores are 10-12 $\mu \mathrm{m}$ long by $8 \mu \mathrm{m}$ in breadth, with 2 flagella, and without chloroplasts. They become infectious after 2 days (22). The presence of a resting stage in the life cycle is not known.

The life cycle of Dissodinium has been partly maintained in culture $(4,21)$. A dinospore attacks a copepod egg with its hypocone. The peduncle-like 


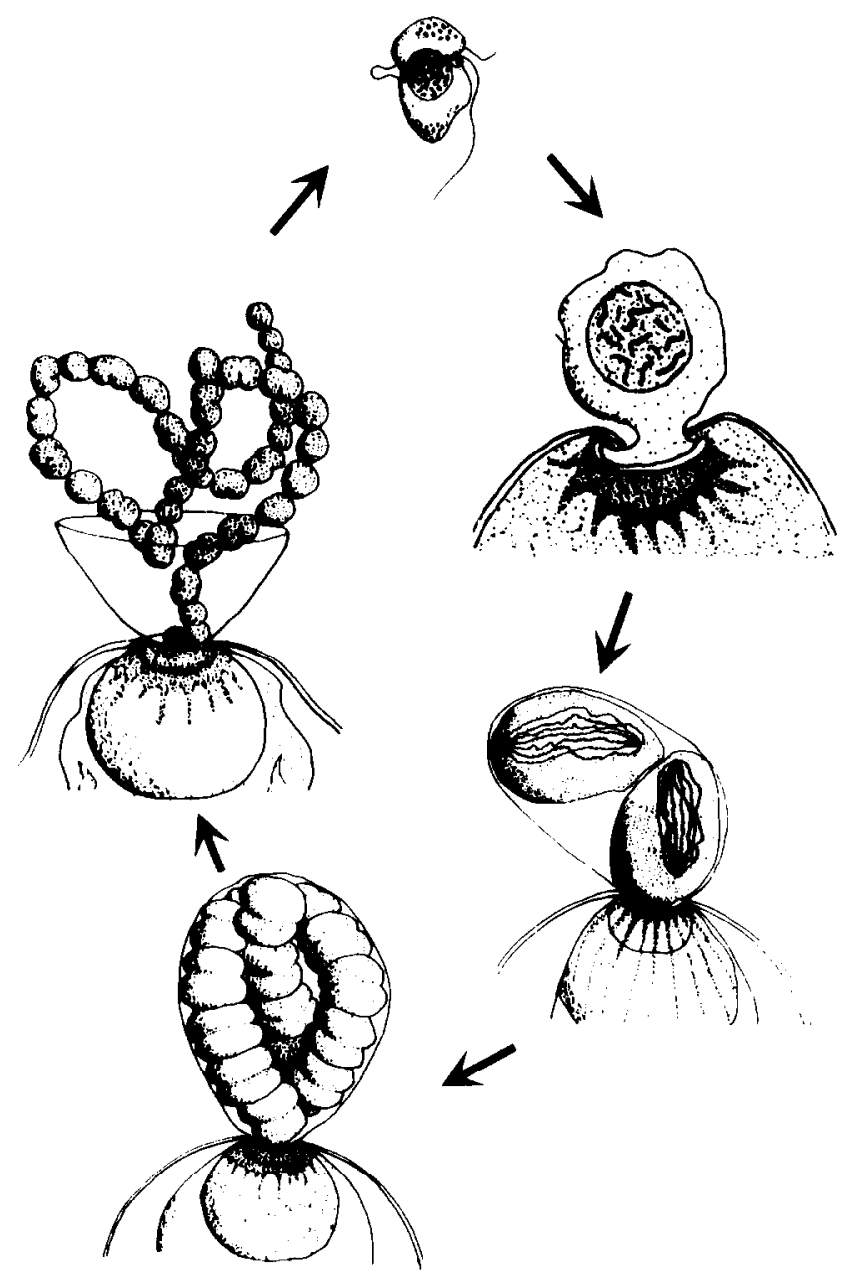

Fig. 2. The life cycle of Chytriodinium affine (reprinted with permission from [6]).

organelle penetrates through the outer coating of the egg and completes phagocytosis of the egg in 70$100 \mathrm{~min}$. During phagocytosis, the dinospore becomes a trophont that grows up to $100 \mu \mathrm{m}$ before detaching from the egg and sporulating. Sporogenesis begins with the development of a cyst wall around the former trophont. The primary cyst undergoes sporogony to produce $8-16$ secondary cysts that each produce, through fission, 3 to 16 freeswimming dinospores. Sporulation is complete after 2 to 3 days (21). Each dinospore encysts after only a few minutes of free-swimming activity. A new dinospore is formed within each cyst, and upon liberation it is capable of infecting a new host. Dinospores remain viable for at least 4 weeks. Curiously, plastids are found in the dinospores of $D$. pseudolunula but not in those of $D$. pseudocalani (4).
Stosch (95) and Drebes (96) noticed a possible resting cyst in the life cycle of $D$. pseudolunula. From plankton samples, two "loosely united" crescentic cysts underwent germination in the laboratory to produce two dinospores. After liberation, the spores again encysted to form a "division cyst" that then produced two dinospores. The latter excysted and shortly thereafter reencysted. Resting cysts of $D$. pseudolunula were found with a marked peak in abundance in late summer and autumn (97). The parasite has an apparent world-wide distribution (98).

The life cycle of Syltodinium listi is considerably different from that of the type genus, Chytriodinium. Free-swimming dinospores of $S$. list $i$ attack copepod eggs where they become trophonts and penetrate the egg coat with a peduncle-like organ- 
(a)

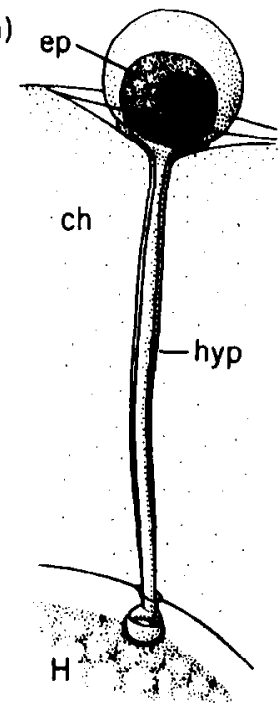

(b)

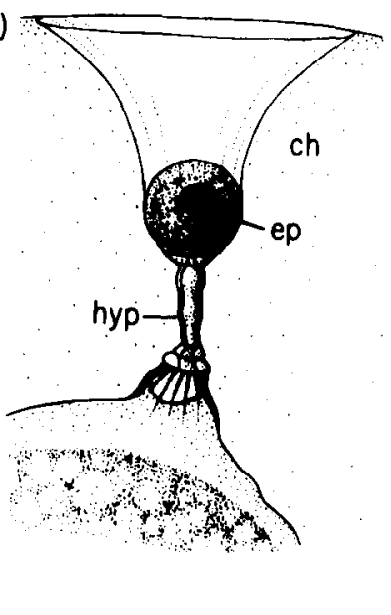

Fig. 3. The attachement and penetration of Chytriodinium parasiticum on an egg of a shrimp (?). Key: ch, chorion of host ova; ep, epicone of parasite; hyp, hypocone of parasite; H, host ova. Reprinted with permission from (6).

elle (cf. hypocone). Trophonts, up to $80 \mu \mathrm{m}$ in length, retain a latent motility. When the contents of the egg are assimilated (ca. $90 \mathrm{~min}$ ), the trophont detaches and forms a gelatinous envelope around a palmelloid multiplication stage in which sporulation occurs. From 16 to 32 colorless, athecate dinospores from $27-33 \mu \mathrm{m}$ in length by $22-27 \mu \mathrm{m}$ in breadth are formed through repeated binary fission (23). After about three days, the dinospores swim free and readily attack the eggs of copepods and rotifers. They remain infective for over two weeks in the laboratory. They, like most of the Chytriodinidae, lack plastids. The presence of a resting cyst in the life cycle is unknown.

General Biology. The holdfasts of the species in Chytriodinium appear well adapted to the eggs of their respective hosts. Chytriodinium affine attacks copepod eggs that have a thin egg coat and little perivitelline space. Its simple holdfast bears rhizoids and small hooks that penetrate through the slight perivitelline space to the cytoplasm of the host embryo (19). Chytriodinium roseum attacks euphausiid eggs that also have a thin egg coat. Its more elaborate holdfast has 5-6 cytoplasmic lobes that are firmly embedded through the egg coat and perivitelline space. The body of the holdfast possesses the ampulla, several large granules, and a pellicle, the whole resembling a large dictyosome (19). The ampulla is an absorptive organelle found in all of the species in the genus (19). Chytriodinium parasiticum attacks the eggs of penaeid (?) shrimp that have a mucilaginous coat and a large perivitelline space. The hypocone of the parasite develops as an elongate tube with an apparently simple holdfast that attaches to the cytoplasm of the host embryo (Fig. 3). Members of the genus are believed to acquire nutrients via extracellular digestion of the host while those in the genus Dissodinium appear to use intracellular digestion (99).

While a single chytriodinid can kill an embryo, as many as four parasites will attack an egg and thrive on its contents $(4,19)$. The size and development of the parasites are, however, affected by the number of feeding trophocytes. Infection by $C$. parasiticum does not necessarily kill the egg. Dinospores may take as long as $\mathbf{2 4}$ hours to penetrate through the mucilaginous coat of the embryo. If the embryo is in the later stages of development at the time of attack, the nauplius may hatch causing the early trophont to die (19).

Epizootiology. Predation and disease are common causes of mortality to the eggs of marine crustaceans (reviewed in 100). The impact of egg predators and parasites on the reproductive output of their hosts has led to the suggestion that they can seriously hinder the population growth of certain host species (101). As with other egg-killing parasites, the Chytriodinidae seem capable of exerting a considerable density-dependent regulation of their host populations; yet their epizootiology is virtually unknown. Anecdotal statements by Cachon and Cachon $(6,19)$ suggest that epizootics of the Chy- 
triodinium spp. may lead to significant host mortality. John and Reid (97) charted the distribution of the resting cysts of $D$. pseudolunula in the North Sea. The widespread distribution and seasonal abundance of the lunate cysts led them to suggest that the parasite may contribute to the large-scale variability in the standing stocks of the hosts. Methods for gauging the affects of these parasites on host populations need to be developed and refined, especially for hosts that spawn planktonic eggs.

\section{SYNDINIDA}

The Syndinida and the Dubosquodinida produce microspores and macrospores $(1,11,27,102,103)$. Infection with either taxa leads to the production of a single spore type within any one host. While Chatton (1) postulates that the different spores may be anisogametes, the functional differences between spore types remains to be determined. The macrospores, microspores and trophonts of Hematodinium sp. have approximately the same DNA concentration per nucleus, which suggests that the spores are not gametes (103). The two spore types of Duboscquella cachoni, which is a parasite of tintinnid ciliates, show variations in their longevity that may lead to differences in their transmission rates (102). Further study of spore morphology and function would facilitate our understanding of the two orders.

\section{Syndinidae}

Members of the Syndinidae are osmotrophic parasites that live in the cytoplasm or body cavities of their hosts. The parasites attack radiolarians, algae and even fish eggs. There are four genera that parasitize crustaceans: Actinodinium, Hematodinium, Syndinium, and Trypanodinium. No significant research has occurred on Actinodinium and Trypanodinium since their original descriptions and later summaries by Chatton $(24,25,93)$. Another genus, Atelodinium, was prematurely placed with the Syndinida, an error promulgated by Chatton's posthumous and unfinished synthesis of the order (25). In an unusual posthumous correction, the genus was synonymized with Paradinium poucheti (40).

Actinodinium apsteini develops in the wall of the stomach of its copepod host, Acartia clausi (24). The large, 75-125 $\mu \mathrm{m}$, trophocyte possesses numerous cytoplasmic rays that project into the hemal sinuses and lumen of the stomach. During its development, a lobe of the trophocyte perforates the intestinal lining and resembles an Oodinium-like infection. The parasite does not castrate its host. The remainder of the life cycle of the parasite is unknown. Its characteristic attachment and general facies suggests an affinity with the family Oodinidae (25).

Trypanodinium ovicola parasitizes the eggs of several different species of copepods. Host eggs are presumably infected when they come into contact with swimming dinospores. The spore enters the eggs and a plasmodium develops internally in the embryo. Sporulation occurs when the contents of the egg are depleted. Little more is known about this parasite. Another egg parasite sharing features of both Trypanodinium sp. and Syndinium sp. was reported from Pandalus borealis by Stickney (28). It was responsible for up to $30 \%$ mortality of the eggs of its host. The potential effect of these parasites on their host populations is unknown, but it may resemble that for the Chytriodinidae.

\section{Syndinium}

Taxonomy. Members of the genus Syndinium are primarily parasites of radiolarians. Three species, however, parasitize crustaceans where they reside in the hemal sinuses or soft tissues of their hosts. The type species, $S$. turbo, was originally described from the hemal sinuses of the copepods Paracalanus parvus, Clausocalanus arcuicornis, and Corycaeus venustus $(1,7)$. A spate of species were listed by Chatton (25) but only one of these, $S$. corycaei, was sufficiently described to be retained (9). Another species, S. gammari, was more recently described from the hemal sinuses of the amphipod Gammarus locusta (26). There are few taxonomic characters to distinguish between the species. Chatton (25) suggests that the morphology of the spore is a primary character, but Cachon and Cachon (6) state that spore morphology is too variable to be useful to taxonomy. More comparative studies that include the type species would clarify our taxonomic understanding of this genus.

Life cycle. The putative life cycle of the genus Syndinium is given in Figure 4. Copepods presumably acquire the infection by ingesting dinospores. After penetrating through the gut wall, a plasmodium develops between the intestinal epithelial cells and the basement membrane $(1,27)$. A host capsule forms around the young plasmodium, but the plasmodium protrudes through the capsule into the body cavity. The plasmodium eventually ramifies throughout the body cavity of the host, filling all of the available hemal sinuses before sporulation. Sporulation takes less than 2 hours. Macrospores and microspores form an annulus and sulcus, and possess 2 flagella. They lack chloroplasts but possess trichosomes $(1,27)$. The dinospores escape 
A
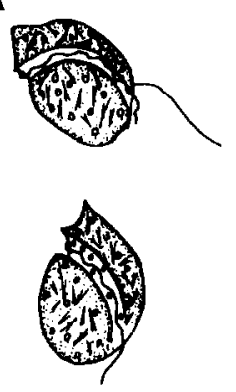

C

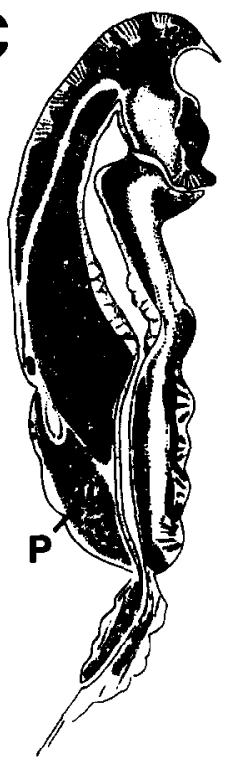

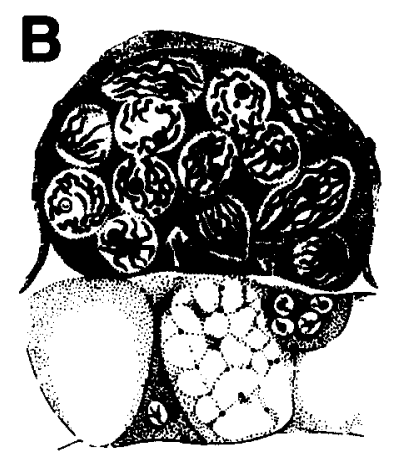

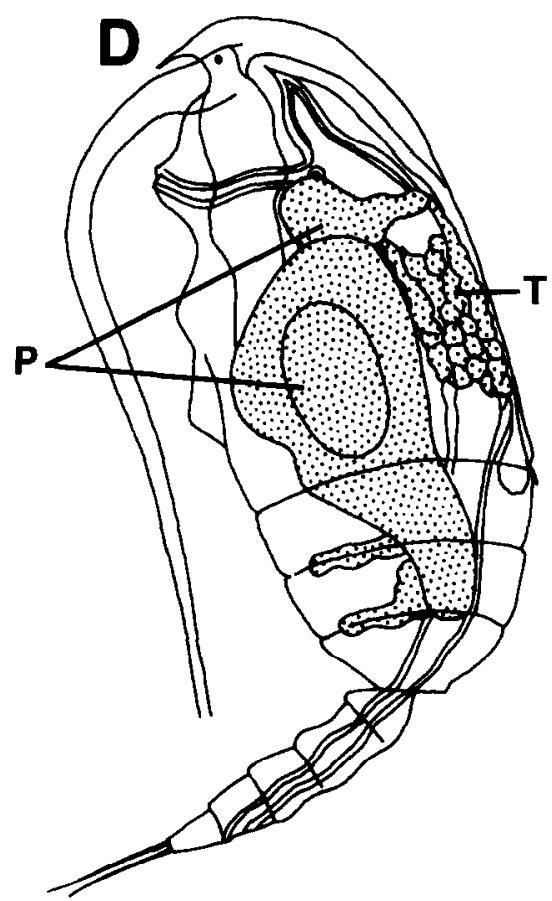

Fig. 4. Generalized life cycle of species of Syndinium turbo. (A) Dinospores (reprinted with permission from Masson and Cie, Eds. [25]); (B) early plasmodium showing numerous mitotic figures (reprinted with permission from Masson and $\mathrm{Cie}$, Eds. [25]); (C) longitudinal section through host showing advanced development of the plasmodium (reprinted with permission from Masson [25]); (D) plasmodial parasite in situ (adapted with permission from [1]); . Key: P, plasmodium; T, testis.

through a slit in the body of the host, typically at the antennae. Their fate thereafter is unknown, but they may encyst on the appendages of their hosts (25).

General biology. Syndinium spp. undergo an atypical form of dinomitosis that distinguishes them from other dinoflagellates [syndinomitosis of Chatton (104)]. There are four distinct features of their nuclear organization: (a) The chromosomes possess functional kinetochores that are inserted into pores in the nuclear membrane; (b) the basal bodies act as centrioles during mitosis; (c) microtubular attachments to the kinetochores and basal bodies persist during the cell cycle; and (d) histones are present in the chromosomes $(105,106,107)$. There are also similarities to the free-living forms: (a) the nuclear envelope does not disappear during mitosis; (b) the chromosomes are permanently attached to the nuclear membrane; (c) during mitosis the nucleus possesses a distinct cytoplasmic channel that contains 
microtubules; and (d) the chromosomes are condensed throughout most of the life cycle $(1,104$, 105,106).

Chatton $(1,104)$ distinguished two types of nuclear division in the life cycle of Syndinium spp: syndinomitosis and synenergide. The genus possesses an enlarged nucleus in the plasmodial stage that does not undergo mitosis until sporulation. This "synenergide" apparently replicates and stores DNA for later sporogenesis (104). From this brief review it is apparent that further studies of the organization of the nucleus, and nuclear division in the taxon are needed.

Pathology. Syndinium infections are considerably more pathogenic to their copepod hosts than those of Blastodinium spp. The early plasmodium of Syndinium is encapsulated by a fibrocytic response, but the encystment is never complete (1). After the plasmodium breaks out of the capsule, it invests the dorsal nerve ganglion and insinuates itself therein $(1,27)$. The parasite then invades and destroys the gonad. As the plasmodium grows, it fills the hemal sinuses, insinuates itself in the muscles, and apparently exerts a considerable physical pressure on other internal organs (27). In advanced stages, the muscles and other organs degenerate and lyse, and the body of the host dilates or swells and becomes opaque (17). In rare cases of double infection, the plasmodia do not fuse $(1,27)$.

In the advanced stages of the disease, there are concretions present in the cytoplasm of the plasmodium (1). Similar concretions are also present in the plasmodium of Paradinium poucheti (27). Jepps (27) thought that the concretions contained fatty storage products necessary for sporulation, but the contents of the concretions, and their role in the biology of the parasites is unknown.

Host castration via the destruction of the gonads is noticeable in the stage IV and V copepodites and in adult females $(1,17,27)$. Curiously, Manier et al. (26) found that $S$. gammari did not castrate its amphipod host. In addition, there is apparently no feminization or change in the behavior of the hosts (27), but the final male ecdysis may be inhibited by the infection (1). Male copepods are rarely infected $(1,17)$ presumably because they are short lived and have reduced feeding capacities when compared to females (108). Such may be the case for the acquisition of other parasites, too. As with Blastodinium spp., infected copepods can mate (15), but it is not clear whether they can survive long enough to produce eggs.

There is scant evidence that the intersex condition of copepods, wherein female copepods bear masculine characters, is caused by parasitic dinoflagellates. While parasites may be found in intersex individuals $(13,15,27,84)$, the causal relationship of the condition to parasitism is doubtful. Ianora et al. (13) found a higher prevalence of intersex hosts with Syndinium infections compared to uninfected hosts ( $20 \%$ vs. $8 \%$, respectively). They presumed that the higher prevalence resulted from castrated hosts having lost the infection. This is unlikely for two reasons: (A) infections are terminal in their hosts $(1,27)$; and (B) the prevalence of intersexes in the population did not coincide with, and did not show an expected lag with the prevalence of infection by Syndinium sp. or Blastodinium sp. Indeed, the intersex condition may arise as a result of the timing of maturation in copepods (109).

Epizootiology. Syndinium spp. have been reported from the Black Sea, the Firth of Clyde in Scotland, the North Sea, Banyuls-sur-mer on the Mediterranean Sea, and the Arabian Sea $(1,7,15$, 16,27,110). Chatton (1) and Jepps (27) suggested that the genus prefers colder waters as it was more prevalent in the plankton in the fall and winter. However, Ianora et al. $(13,17)$ provide quantitative data that show distinct summer-autumn patterns for several years of data in the Gulf of Naples.

Epizootics of Syndinium spp. have been reported from Loch Striven, Scotland, the Gulf of Naples, southeast Australia, and the Mediterranean Sea $(1,13,14,17,45)$. Prevalences of up to $30 \%$ have been reported. The mortality rates of infected copepods were much higher than those of uninfected hosts (14). In laboratory tests, the median mortality due to Syndinium sp. was $10-41 \%$ of the laboratory population per day compared to $16 \%$ per day due to other causes. The mortality rates for infected individuals were $0.64-1.37$ hosts per day, which were significantly more than the negligible mortality experienced by the uninfected hosts. Infected copepods were not more susceptible to fish predation (14), but moribund hosts were not tested. Kimmerer and McKinnon (14) estimated the peak mortality of $42 \%$ per day for the epizootic reported by Ianora et al. (13). These studies are the first to indicate that these parasites can play a significant role in regulating their host populations.

\section{Hematodinium}

Taxonomy. Members of the genus Hematodinium are primarily parasites of decapods. There is only one described species in the genus, but several of the recently documented forms warrant species status (Table 1), and one new species is pending 
(34). The type species, Hematodinium perezi, was originally described from the portunid crabs $\mathrm{Carci}$ nus maenas and Liocarcinus (=Portunus, = Macropipus) depurator from France (5). It was originally found in only 4 of 3570 crabs (5), but more recently it was reported at high prevalences in Cancer pagurus, and Necora (=Liocarcinus, =Portunus) puber $(29,30)$. It or related species have been identified from a wide range of host species from many geographic regions (Table 1).

The genus Hematodinium needs better taxonomic definition. Electron microscopy studies of the type species are badly needed to further the taxonomy of the genus. Other problems make taxonomic studies difficult. For example, the dinospore, which may have taxonomic value, has not been observed in the type species; it has only been observed in the species that infects Chionoecetes bairdi $(11$, $36,103)$. To further complicate specific identification, there are few morphological differences between parasites from different hosts. For example, the plasmodia observed in $H$. perezi from Callinectes sapidus, Carcinus maenas, and Liocarcinus depurator is vermiform and motile, but those from Chionoecetes bairdi, Portunus pelagicus, and Scylla serrata are round and immotile $(5,11,34)$. In Nephrops norvegicus, the plasmodia are round, except when attached to host tissues (12).

Life cycle. The putative life cycle of the genus Hematodinium is shown in Figure 5. Crabs presumably become infected by ingesting infectious spores, although other routes of infection, such as cannibalism with the ingestion of infectious trophonts, have not been ruled out. The trophonts live in the hemolymph and rapidly proliferate via schizogony. The plasmodia possess 2-8 nuclei and are motile in $H$. perezi but not in other forms. Sporulation has only been observed in the form that infects the Tanner crab, Chionoecetes bairdi $(11,36)$. Dinospores presumably exit the host via small tears in the exoskeleton but other avenues like egress from the antennal glands have not been ruled out. Macrospores $(15 \mu \mathrm{m})$ and microspores $(8 \mu \mathrm{m})$ (see Syndinida) can survive in seawater for several days, but their fate is unknown.

Variations on this life cycle occur primarily in the timing of transmission and the development of parasites in different hosts. For the parasite from C. bairdi, infections may take 9-18 months to sporulate (36), but infection experiments with Portunus pelagicus and Scylla serrata, suggest a much shorter duration in the life cycle of their parasites (34). Transmission experiments with the parasite in C. bairdi and $P$. pelagicus have been successful only when trophonts or dinospores are injected into naive hosts $(11,34)$. The parasites have not been transmitted to crabs via exposure to free-swimming dinospores.

Cannibalism has been suggested as a possible route of transmission as it functions as such for other crab parasites (111). Hudson and Shields (34) were, however, unable to transmit Hematodinium

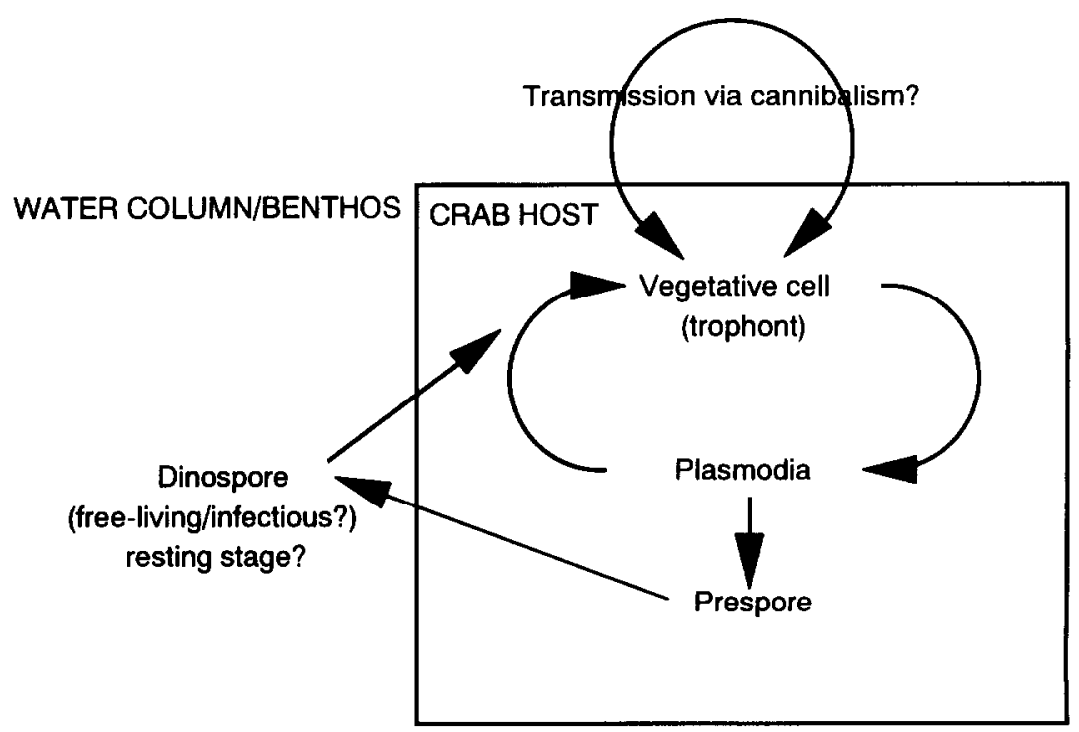

Fig. 5. Putative life cycle of Hematodinium perezi. 
$\mathrm{sp}$. via cannibalism. They speculate that benthic amphipods, which are a component of the diets of many decapods, may act as intermediate or reservoir hosts in the life cycle of the parasites. The recent discovery of Hematodinium-like parasites in benthic amphipods and neritic shrimp (37-39) may present an opportunity to investigate this hypothesis.

Pathology. Early and moderate infections of Hematodinium can be difficult to diagnose. In wet smears the trophonts resemble immature hemolymph cells; their granularity, their oval or ellipsoidal appearance, and, in some cases, their sheer abundance are clues to a proper diagnosis (Fig. 6). In stained blood smears, the trophonts are distinguished by their ever-present dinokaryon (condensed and darkly staining chromatin), or by the presence of plasmodia that are distinct from Paramoeba perniciosa. In late stages of the infection the hemolymph is creamy white in color because of the abundant trophonts. The main symptom of the infection is lethargy.

In crabs and lobsters the route of infection may be through the gut as lightly infected hosts exhibit a disruption of the muscle layer surrounding the midgut (12). As the parasite proliferates, the disease progresses with the degeneration of the hepatopancreas and muscles, and a general congestion of the gill filaments and hemal sinuses with trophonts and plasmodia $(11,12,29,34,88)$. Proliferation in the hemolymph results in a dramatic reduction in the hemocytes of the host even though the trophonts are not found intracellularly $(11,32)$. Respiratory dysfunction is indicated by the low oxygen-carrying capacity and the reduced copper concentrations of the hemolymph of infected crabs (12). Respiratory dysfunction may also explain the lethargy of the host. Disruption of the hemolymph cells may result from the sheer number of trophonts in the blood and their contact with the host cells. Nonetheless, the mechanisms that cause the lysis of the hemolymph cells and the reduction in oxygen capacity of the sera remain to be explained.

Host mortality has been indirectly assessed for the Tanner crab, C. bairdi, and the Norway lobster, $N$. norvegicus. The mortality of infected $C$. bairdi held in aquaria for 97 days was $67 \%(N=11)$. None of the uninfected crabs died (11). Infected lobsters held in aquaria were moribund and had mortality rates that were two to four times that of uninfected controls (12). While difficult to establish, the above authors suggest that mortality in the field may be substantial during the epizootics. Infections are generally considered terminal.

Epizootiology. Several host and environmental factors are important to the infection dynamics of Hematodinium spp. The molt cycle and sex of the host appear to contribute to the transmission of Hematodinium spp. Considerably more postmolt C. bairdi were infected with Hematodinium sp. than were those in intermolt $(36,103)$. Dinospores were not present, however, in infected crabs during the ecdysial season (April-June); they were present in late summer, after ecdysis. Similar, but inconclusive, findings were reported for the parasite in $N$. norvegicus (12). Perhaps the stress of molting leads to proliferation of the parasite (36). In addition, no differences were observed in the size or sex of infected C. bairdi (36), but female and juvenile $N$. norvegicus were more frequently infected than the older males (12). Thus, the route of transmission to new hosts and the maturation period in infected hosts are still in doubt.

Seasonal outbreaks of Hematodinium spp. implicate temperature as a key factor in recurring epizootics. In the American blue crab, Callinectes sapidus, the disease is most prevalent in the late summer and fall $(32,88)$, and may be related to shallow lagoon habitats with high water temperatures. In Chionoecetes bairdi, the prevalence of infection peaks in late summer $(36,103)$, but in Liocarcinus puber from France, the parasite is most prevalent in winter (29).

Salinity may play a distinct role in the epizootiology of the disease in estuarine hosts. In Chesapeake Bay, salinity appears to regulate the distribution of $H$. perezi in Callinectes sapidus (112). There, the parasite has only been found in salinities greater than $11 \mathrm{ppt}$. It is typically found in the lower Chesapeake Bay and in the subestuaries along the Delmarva Peninsula. Since male crabs prefer less saline waters than females $(113,114)$, it is intuitive that more females will be infected by the parasite than males. Interestingly, Messick (88) shows that juveniles have a significantly higher prevalence than adult crabs. In some locations all of the juvenile crabs were infected and presumably died.

Epizootics of Hematodinium have been reported from southeast Alaska, Scotland, France and the eastern seaboard of the USA $(12,29,30,32,36)$. Unfortunately, the parasite has had a significant impact on several fisheries. In Chionoecetes bairdi, Hematodinium sp. causes a condition known as bitter crab disease. Localized epizootics in which 80 $95 \%$ of the crabs are infected have led to effective losses to the fishery of $10-48 \%$ of the catch $(11,36)$. In Nephrops norvegicus, the prevalence of Hematodinium sp. may reach $70 \%$ in trawled samples with noticeably high levels of moribund hosts (12). 

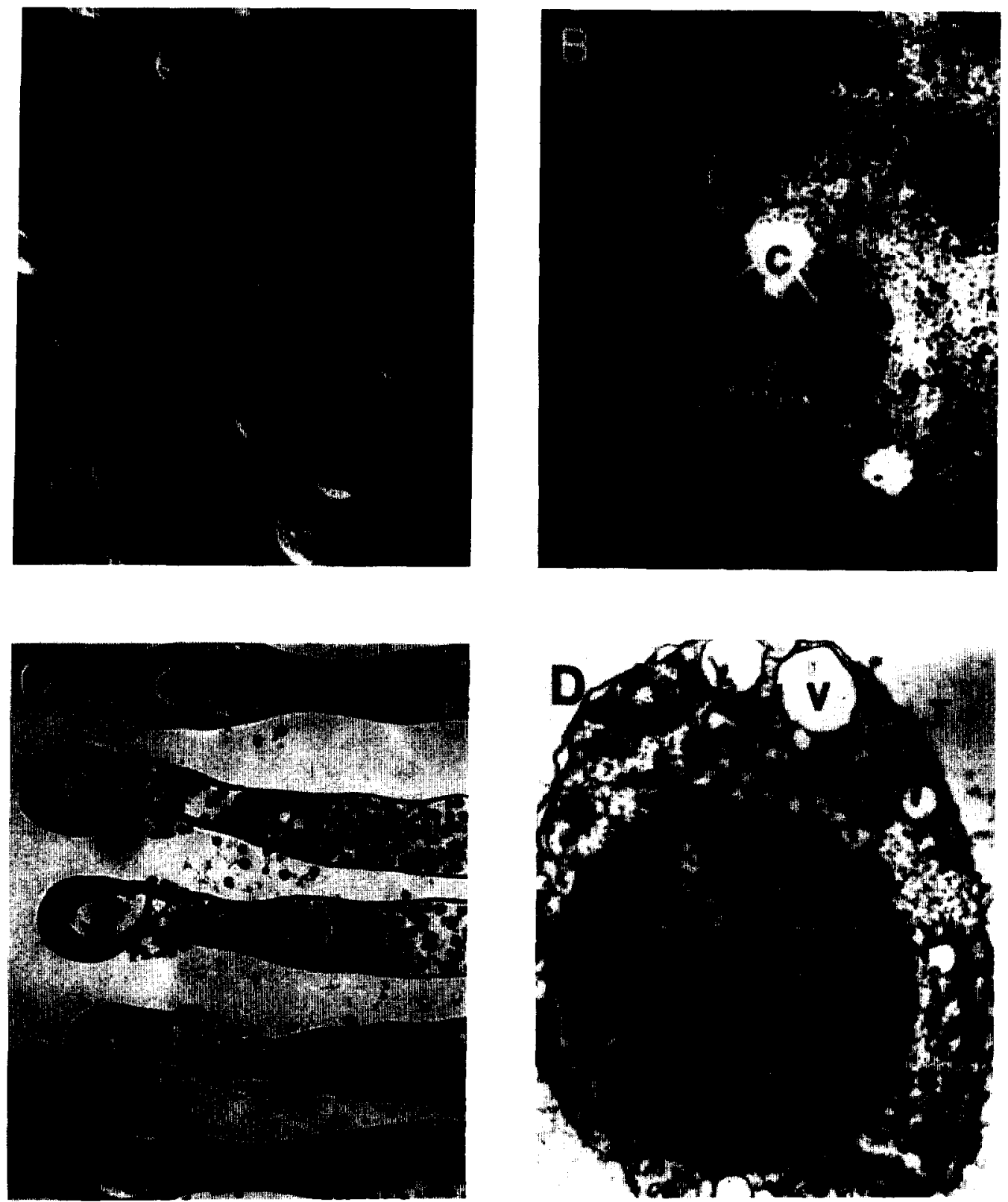

Fig. 6. Hematodinium "australis" from Portunus pelagicus. (A) Wet smear of live trophonts (12-14 $\mu \mathrm{m})$ in crab hemolymph, Nomarski; (B) dried muscle smear showing trophonts $(10-11 \mu \mathrm{m}) ; \mathrm{C}$, condensed chromatin in nucleus; Wright's stain; (C) section of crab gill showing high intensity infection (reprinted with permission from [34]; (D) trophont (approx. $10 \mu \mathrm{m}$ wide) with trichocysts $(\mathrm{t})$, condensed chromatin (c), vacuole (v), and nucleus (n) (B-D reprinted with permission from [34]).

In Callinectes sapidus, a prevalence of $30 \%$ was reported from Florida, where its impact on the crab population was thought to be high (32). Along the Delmarva Peninsula, the prevalence of the parasite may reach $100 \%$ and is associated with a mortal- ity of over $50 \%$ in harvested crabs $(88$, Shields and F.O. Perkins, unpubl. data).

Epizootics of Hematodinium spp. have caused significant losses to the affected fisheries. In the 1988/1989 season, the afflicted Tanner crab ( $C$. 
bairdi and $C$. opilio) industry was estimated to have lost almost $10 \%$ of its market $(\$ 220,000)$ to bitter crab disease (36). In the highly valued ( $\$ 20$ million) Norway lobster industry, the parasite is starting to have a noticeable impact; it has an estimated prevalence of $10-30 \%$. Perhaps more important though is the potential affect of the parasite on the benthic community. Since Callinectes sapidus is a dominant organizer of the benthic infaunal community (115117), and since it experiences major epizootics, I speculate that the reduction or loss of large populations of predatory crabs may result in significant changes to the structure and organization of their associated benthic communities. These host-parasite systems may be ideal for studying the effect of biological perturbation on what are thought to be relatively stable benthic communities. The nidi of infection are located in geographically isolated areas; these areas may be useful for natural field experiments on the parasite-derived changes to the community.

Recent outbreaks of egg-predatory nemerteans, rhizocephalan castrators, and dinoflagellates on crabs and lobsters have seriously affected or even devastated host populations in California, British Columbia, Alaska, and Scotland $(11,12,36,101$, $118,119)$. The causative agents were virtually unknown until the occurrence of the epizootics with the resultant losses to the fisheries. In Alaskan waters, environmental factors such as hydrographic conditions and seasonal increases in water temperature (i.e. fjords with shallow sills) appear to have contributed to the epizootics (118-120). Recent models suggest that closed populations of hosts may be more seriously affected by parasites than those populations that are open (121). (Open and closed refer to larval recruitment patterns and the flush rate of the environment of the host.) These models may help in the effective management of the afflicted stocks.

While the evidence is circumstantial, the apparent reduction in water mixing and flushing in the isolated fjords of Alaska and Scotland may be a factor in the increased prevalence of Hematodinium sp. in $C$. bairdi and $N$. norvegicus. That is, the epizootics occur in relatively closed or "contained" areas. In Virginia, the shallow lagoons and backwaters of the Delmarva Peninsula may be ideal for the growth and spread of protozoan diseases in the blue crab. From this I speculate that a triad of conditions are required for the continued epizootics of Hematodinium: (a) rclatively closed crab populations (i.e. those with little immigration and emigration of juveniles and adults), (b) relatively little water exchange between the open ocean and backwaters (i.e. narrow channels with shallow sills and barrier islands/bars), and (c) stressful conditions for the crab populations (heat and salinity stress, seasonal hypoxia, seasonal fishing and predation pressure). In contrast, well flushed estuaries or oceanic waters may not support such recurring epizootics (118).

\section{PARADINIDA}

\section{Taxonomy}

The Paradinida are plasmodial parasites that occur in the body cavities of copepods. The taxonomic characters that separate Paradinium from Syndinium justify the placement of the former in a separate order $(1,41)$. These characters are (a) the binucleate state of the amoeboid stage (Paradinium lacks the typical dinokaryon), (b) the possession of filopodia and the development of a reticulum in the host, (c) the external sporulation and formation of a mucoid cyst, and (d) the possession of functional centrosomes during mitosis. On the basis of nuclear development and flagellar organization, the order is more closely allied with the Mycetozoa $(40,41)$. The order currently possesses only one genus with three species (Table 1, see also Syndinium taxonomy). Three characters are used to distinguish the three species of Paradinium: the number of chromosomes in and the size of the nuclei, and the different hosts (40).

\section{Life cycle}

The life cycle of Paradinium has features that are distinct from that of Syndinium (Fig. 7). An amoebula develops from a Bodo-like spore ("bodonispore") and is presumably ingested by a copepod host. It penetrates into the lining of the intestinal wall and develops as a small $(5-7 \mu \mathrm{m})$ amoeboid plasmodium. The plasmodium has a bipolar spindlelike shape with fine filopodial extensions (1). As the filopodia develop, they fuse and ramify throughout the body cavity. They invade the nerves and gonads, and develop to form a sheet-like reticulum that further grows into a massive plasmodium (27). At this stage in the infection there are two plasmodial forms: a general mass of quiescent nuclei, and superficial "islands" or "blastodes" with crowded, active nuclei that are a part of the main mass of the plasmodium. Perhaps these blastodes eventually develop into the "gonospheres" or "sporospheres."

Once the parasite fills the hemal sinuses, sporulation is initiated. With Paradinium, plasmodial fragments migrate into the digestive tract of the host where they are expelled from the anus as multinucle- 

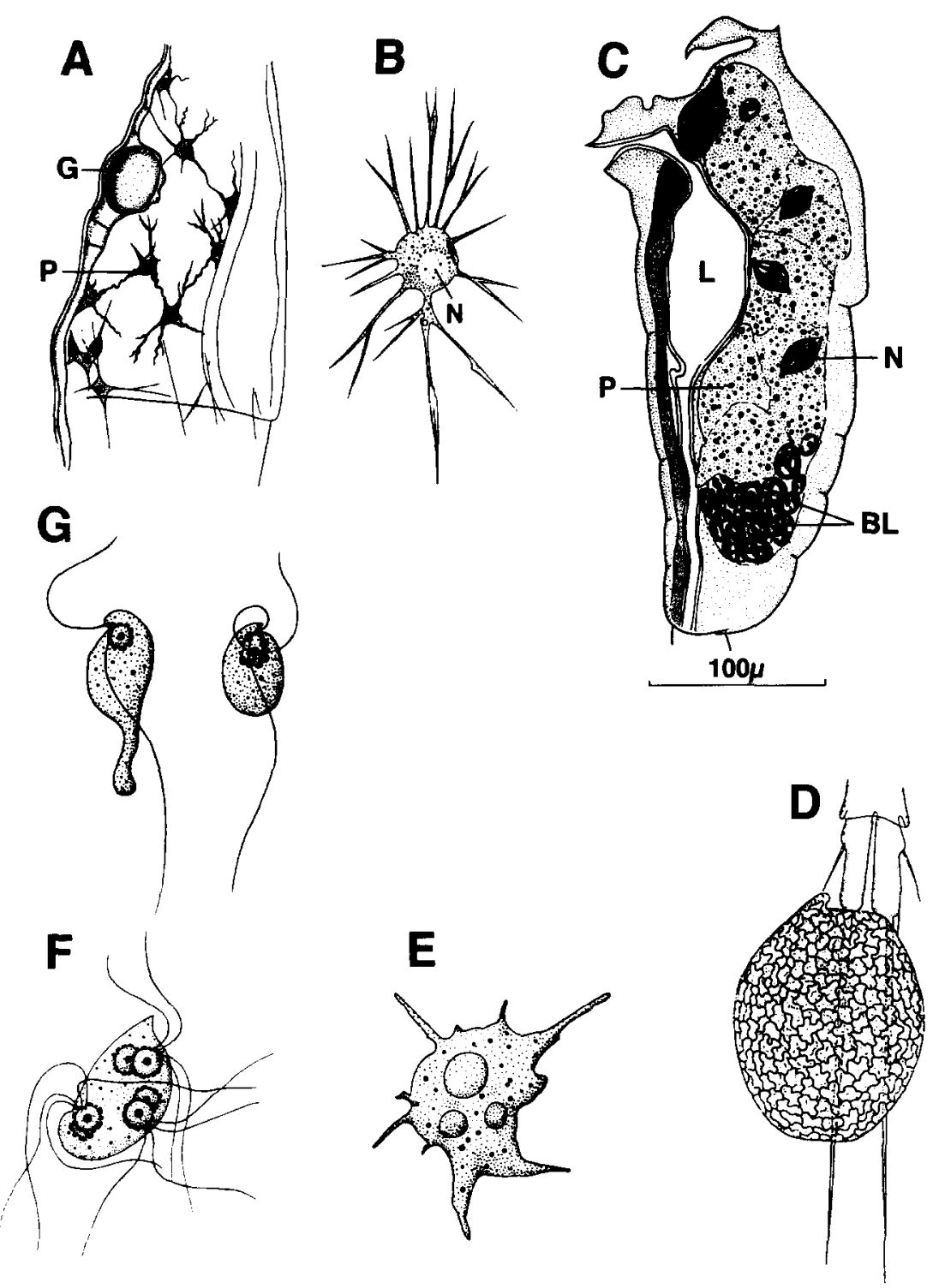

Fig. 7. Putative life cycle of Paradinium poucheti. (A) Early plasmodium with filopodial extensions (reprinted with permission from Masson and Cie, Eds. [123]); (B) plasmodium with filopodia (reprinted with permission from Masson and Cie, Eds. [123]); (C) blastodes in situ (reprinted with permission from [40]); (D) gonosphere attached to host (adapted with permission from [1]); (E-G) amoebulae and bodonispores (reprinted with permission from [41]). Key: BL, "blastodes"; G, large globule in wall of intestine; L, lumen of stomach; N, nucleus; P, plasmodium.

ated "gonospheres" $(90 \mu \mathrm{m})$. The number of fragments that sporulate is dependent upon temperature (40). The gonospheres secrete a mucoid or gelatinous cyst wall and attach to the caudal rami or furca of the copepod. The orange-colored cysts may, sometimes, be longer than the host, but the host appears to swim normally, in some cases with a "large orange flag behind it" (27). After the expulsion of the gonospheres, the internal residuum of the par- asite does not thrive and fails to produce more gonospheres. Some copepods may survive the infection, but their mortality is no doubt hastened by the disease $(27,41)$.

After an hour, sporulation is discernible within the gonosphere. It proceeds as the development of small ameboid bodies having two flagella (the gonosphere and contents are called the presporal filoplasmodium). The amoeboid bodies undergo 
meiosis to form "bodonispores" $(40,41,122)$. The gelatinous wall then dehisces, the inner sporocyst wall ruptures and the bodonispores swim free. The spores are $12 \mu \mathrm{m}$ long, possess trichosomes, and have a beak that superficially represents a degenerate sulcus $(1,27)$. Sporulation may take several hours or several days, and is dependent upon temperature $(27,40)$. In rare cases, sporulation may take place internally with spores exiting through a break in the cuticle $(1,27,40)$; this character led Chatton (1) to erroneously erect the genus Atelodinium (40). Based on turnover in copepod stocks, Marshall et al. (45) estimated that the life cycle of $P$. poucheti took 4 weeks.

Attempts to establish the life cycle of Paradinium poucheti have been unsuccessful $(1,27,41)$. Transmission experiments with bodonispores have, however, shown that they develop into small amoebulae on the external surfaces of exposed hosts. The amoebulae are active and do not possess trichosomes. Chatton $(1,40,122)$ observed meiosis in the gonosphere of Paradinium. Since the bodonispore may be a gamete, the next stage, the amoebula, may represent the zygote $(1,122)$.

\section{Pathology}

Paradinium infections have a similar pathology to that of Syndinium $(1,27)$. The early plasmodium is encapsulated by a fibrocytic response, but the parasite evades complete encapsulation. "The parasite occupies the gonads and pushes out between the body muscles to form 'parietal sheets' inside the body wall and continuous with a perineural investment. This is developed early in the infection and may penetrate deep into the nervous tissue itself" ( 1 in 27). The filopodial extensions also insinuate through the muscles of the host. The abdomen and limbs of the host are only rarely invaded $(1,27,41)$.

There are two types of concretions that occur in the cytoplasm of the plasmodium in the advanced stages of the infection (27). Large fatty concretions form in the plasmodium surrounding the digestive tract of the host. These concretions change after sporulation and become eosinophilic inclusions. Rod-shaped crystalloid bodies (1-2 $\mu \mathrm{m}$ long) also occur in the cytoplasm after sporulation. The role of the concretions in sporogenesis is unknown. Jepps (27) speculated that the various concretions serve as storage products for sporogony.

Host castration occurs because of the invasion of the gonads of the infected hosts $(1,27)$. Castration is not, however, a necessary outcome of the infection (41). In addition, feminization of the host does not typically occur $(1,27,41)$, but there is some evidence to the contrary. Chatton (1) found that male copepods were rarely infected by $P$. poucheti. Jepps (27) found the parasite in 7 males, $143 \mathrm{fe}$ males, and in 114 stage $V$ copepodites. These results can be explained if males are inhibited in their final ecdysis or if their secondary sexual characters are affected by the parasite (i.e. feminization). Alternatively, the behavior of the male hosts may differ from the females and juveniles as the former may have a decreased chance of acquiring the infection (see Syndinium pathology [108]).

\section{Epizootiology}

Paradinium poucheti has been reported from the Firth of Clyde, and the Mediterranean Sea $(1,27,41,124)$. The Atelodinium spp. from the Gulf of Naples and southeast Australia are misidentified species of Syndinium $(13,14,17)$. Given the life cycle and pathology of the Paradinida, it seems likely that they may affect their host populations like the Syndinida, but there is no evidence of their occurring in epizootic proportions.

\section{ELLORIOPSIDAE}

The Ellobiopsidae have been variously classified as members of the Pyrrhophyta (=Dinophyta) $(1,46)$, the Sarcomastigophora $(49,125)$, and the Fungi $(27,59)$. The zoospore of Thalassomyces marsupii is biflagellate in a manner consistent with the dinoflagellates but that of Parallobiopsis coutieri is uniflagellate and not so consistent $(71,125)$. The Ellobiopsidae is undoubtedly a heterogeneous family and it is this nature that has precluded, in part, a definitive systematic placement of the taxon or its diverse members (43). For substantive reviews of the earlier literature, including notes on geographic distributions, see Chatton (1), Boschma $(43,61)$ and Wing (54).

\section{Taxonomy}

Members of the family Ellobiopsidae live primarily as external parasites of pelagic crustaceans. There are four genera that parasitize crustaceans (Ellobiocystis, Ellobiopsis, Parallobiopsis, and Thalassomyces) and one monotypic genus that parasitizes a benthic polychaete (Rhizellobiopsis eupraxiae) (Table 1). The genus Ellobiocystis may warrant separation from the other members of the family $(43,61)$, but I believe it shares too many features with Ellobiopsis to be removed from the family.

The Ellobiopsidae exhibit an interesting progression in morphological complexity that is useful in distinguishing the genera (Fig. 8). The genus Ellobiocystis has a single trophomere attached to the host via a noninvasive mucoid stalk; one to two gono- 
A

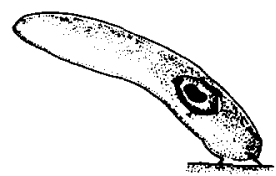

Ellobiocystis

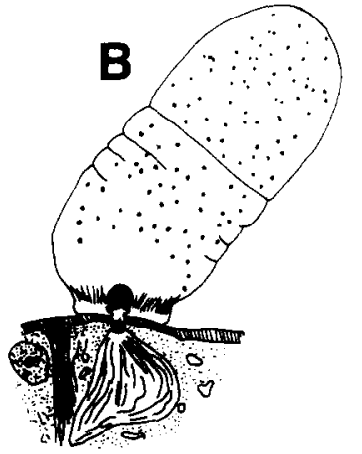

Parallobiopsis

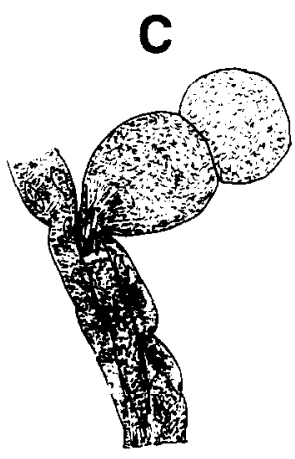

Ellobiopsis

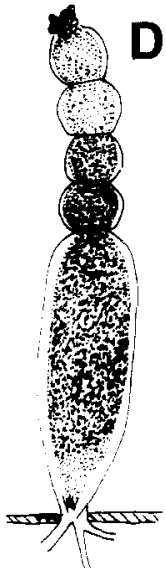

Rhizellobiopsis

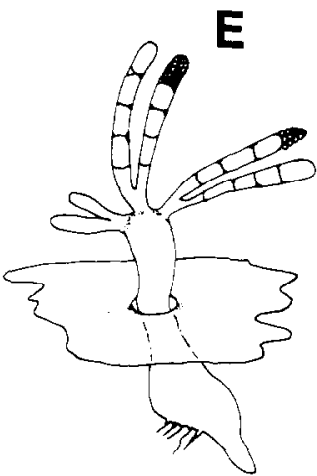

Thalassomyces

Fig. 8. Forms of the genera in the Ellobiopsidae. (A) Ellobiocystis (adapted with permission from Masson and Cie, Eds. [126]); (B) Parallobiopsis (adapted with permission from Masson and Cie, Eds. [126]); (C) Ellobiopsis (adapted with permission from Masson and Cie, Eds. [126]); (D) Rhizellobiopsis (adapted with permission from Masson and Cie, Eds. [126]); (E) Thalassomyces (adapted with permission from [54]).

meres arise from the trophomere. Species of Ellobiopsis possess a trophomere with a single, invasive peduncle for host attachment; multiple gonomeres arise from the trophomere. Parallobiopsis coutieri has a trophomere with a sucker-like holdfast and a simple, invasive peduncle; a single gonomere generally develops from the trophomere. Rhizellobiopsis eupraxiae has a trophomere with an invasive multi-rooted peduncle; gonomeres arise sequentially in a single chain (cf. meristem) originating from the trophomere. Species of Thalassomyces have a specialized, internal organ of fixation (with protoplasmic excrescences or rootlets) that produces multiple trophomeres, each in turn producing multiple gonomeres.

The four recognized species of Ellobiocystis primarily infect shrimps and mysids. Coutière (42) described seven species and several forms but many of these were later synonymized by Chatton (1) and Boschma (43). Other authors have at different times recognized various of Coutière's forms. I have retained only those species not specifically questioned by previous authors (Table 1). There is considerable morphological variation within the genus, and few distinguishing characters on which to base proper identifications. More cytological and ultrastructural work would help to delineate the different species in this genus.

The genus Ellobiopsis contains three species that primarily infect copepods. The species are distinguished on the bases of the sizes of their trophomeres and whether they possess one or two gonomeres. Boschma (43) notes that except for its smaller size, $E$. fagei is virtually identical to $E$. chattoni. He suggests that the differences may be a result of the size of the host. If such is the case, then $E$. fagei may 
be a synonym of the latter. Several authors have noticed a possible species complex for Ellobiopsis chattoni. Wickstead (90) found that populations of Undinula vulgaris var. major were heavily infected by $E$. chattoni, yet other host species were not infected. Similar findings have been reported for $E$. chattoni on Metridia longa and Pseudocalanus minutus $(54,57)$. This host specificity suggests the presence of several new species of Ellobiopsis.

The monotypic Parallobiopsis coutieri is attached to the pleopods, gills, and the folds of the cephalothorax of its host Nebalia bipes. Sporulation results in uniflagellated spores that do not resemble dinospores (125). Rhizellobiopsis eupraxiae appears closely related to $P$. coutieri but is distinguished from the latter by the presence of a divided root system $(53,127)$. Both species can bear more than one gonomere on the trophomere.

The genus Thalassomyces is the best known of the ellobiopsids because its members bear large trophomeres that protrude overtly from the bodies of their hosts (Fig. 8). The genus contains 12 species that are known to infect a variety of pelagic and benthic hosts from several different taxa (Table 1). The genus has undergone several revisions having first been described as Staphylocystis Coutière, 1911, which was later found to be occupied, and Amallocystis Fage, 1936, which was replaced by priority with Thalassomyces Niezabitowski, 1913 (43). There are several useful characters to discriminate between species: the size and the shape of the trophomeres and gonomeres, the number of gonomeres arising from each trophomere, and the location of the infection and the host family $(43,54,61)$. There may be a positive correlation between the size of the hosts and the size of the trophomeres that could lessen the value of this taxonomic character (43).

\section{Life cycle}

The generalized life cycle of Ellobiopsis spp. is shown in Figure 9. Ellobiocystis spp. are thought to have similar life cycles to Ellobiopsis. A spore with flagellates presumably settles on or adjacent to a seta of a buccal appendage of its host and develops into a trophomere (66). In Ellobiopsis, the trophomere possesses a simple root-like organelle that penetrates through the host cuticle and apparently functions in absorption. Sporulation in Ellobiopsis fagei occurs as the gonomere becomes tightly constricted from the trophomere, and groups of dividing cells are released from the remains of the gonomere. The cells further differentiate and divide to form nonflagellated spores (51). The fate of the spores is unknown. It is also not known if the trophomere continues living thereafter (27). In $P$.

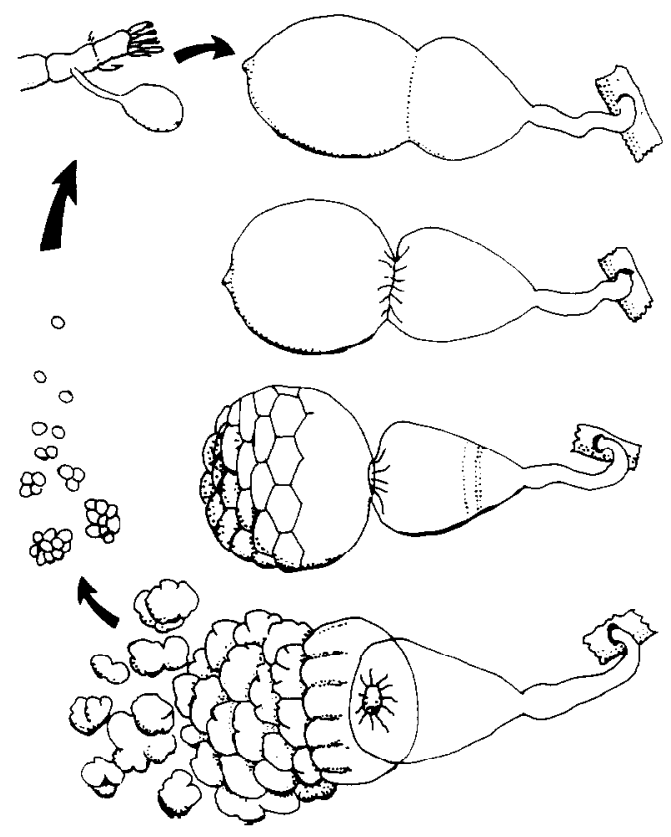

Fig. 9. The life cycle of Ellobiopsis (adapted with permission from [51]).

coutieri, sporulation begins with the migration of the nuclei to the periphery of the gonomere that undergoes cytokinesis to produce uniflagellated spores $(125,127)$.

The life cycle of Thalassomyces is considerably different from that of Ellobiopsis (Fig. 10). The infection is presumably acquired via the ingestion of an infectious spore $(61,68)$. The spore apparently migrates into the somatic tissues of the host where it develops into an organ of fixation. The organ of fixation absorbs nutrients via attached rootlets and grows in size until the trophomeres push through the cuticle of the host (presumably at ecdysis). Gonomeres bud atop the trophomeres and sporulation proceeds as in Ellobiopsis but biflagellated "dinospores" are produced (71).

In euphausiids, data gleaned from host infection dynamics suggest that the life cycle of $T$. fagei may take about one year (63). All of the infected hosts belonged to the I-group (age class) meaning they had hatched and were presumably infected during the previous year. From this data, Mauchline (63) speculated that infection took place 10 months before the production of trophomeres.

\section{Pathology}

The genus Ellobiocystis does not invade or penetrate the body of its host. The location of the species around the buccal appendages indicates a 

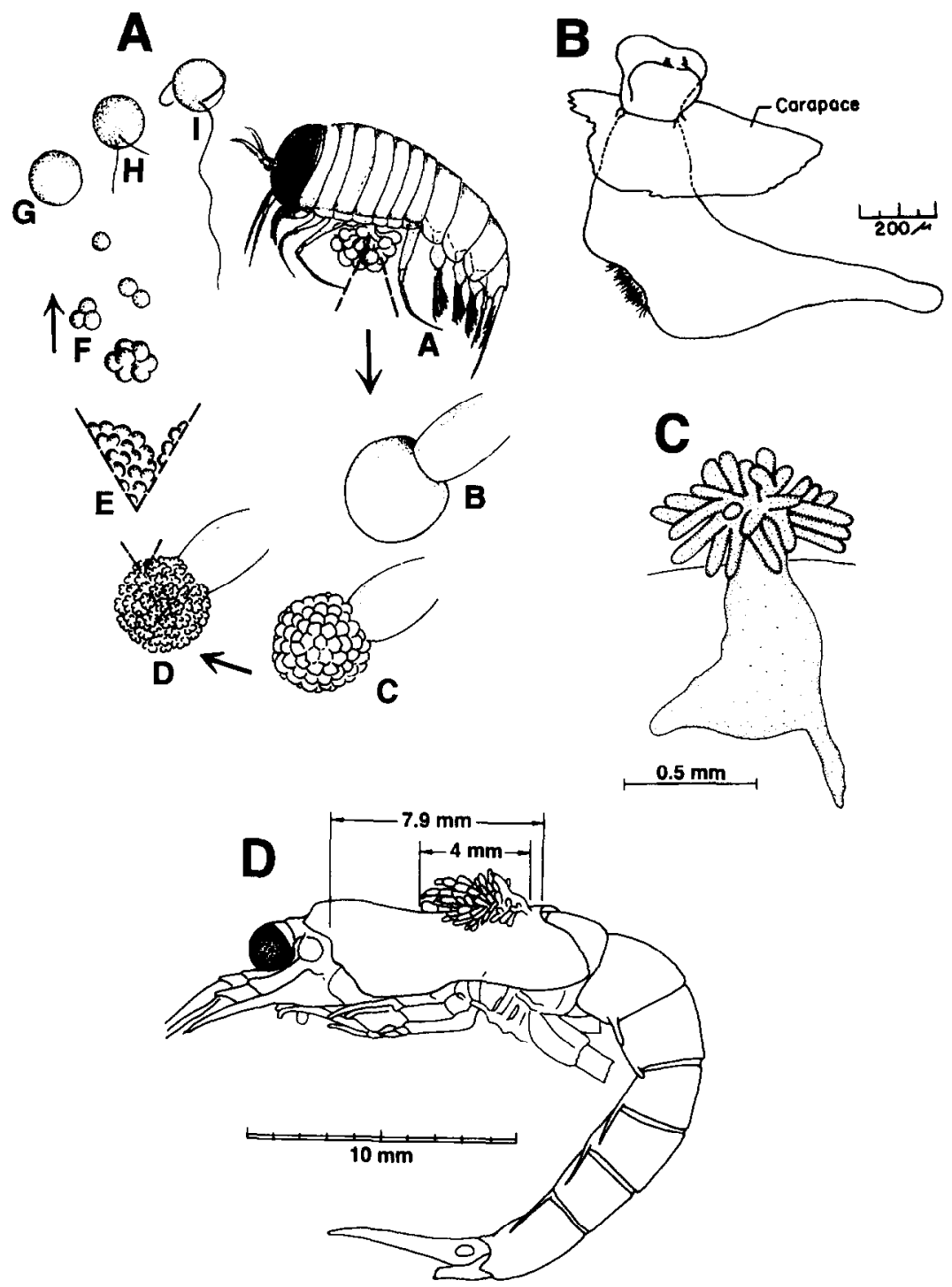

Fig. 10. The life cycle of Thalassomyces. (A) Putative life cycle of T. marsupii in an amphipod host: A, host with parasite; B-F, sporulation; G-1, development of the zoospore (reprinted with permission from [71]); (B) developing T. fagei showing extent of organ of fixation (Journal of the Marine Biological Association of the U.K. (1966) 46: Fig. IE, by Mauchline. Reprinted with the permission of Cambridge University Press); (C) mature T. fagei. (Reprinted from Pacific Science 20: 70-78 [Fig. 4] by Hoffman \& Yancey with permission; (C) 1966 by University of Hawaii Press); (D) Stilomysis major infected with Thalassomyces albatrossi (reprinted with permission from [54]).

commensal relation with their hosts (1). The other members of the Ellobiopsidae are parasitic and penetrate the cuticle in a variety of ways to gain their nutrition.

Little is known about the pathology of Ellobiopsis chattoni infections. The penetration of the invasive stalk into the appendage of the host causes localized damage to the surrounding musculature. While a host may be infected by many early stages of the parasite only one or two trophomeres ever mature at one time (27). Infection by the parasite can lead to host castration but castration is often incomplete (i.e. reduced fecundity) and is dependent upon the number of parasites present $(27,90)$. Castration takes the form of a disrupted ovarian cycle with disorganized ovaries, and undeveloped or poorly developed oviducts $(27,90)$. Wickstead $(90)$ calculated that a large parasite has a volume of 5.0- 
$7.5 \%$ of that of its host. Since typically only two trophomeres develop fully on a host, she states that the parasites "would be a considerable drain upon the resources of the copepod that would in effect cause the animal to starve." Since starvation inhibits egg production, castration by $E$. chattoni may be reversible $(90)$.

Infections by Thalassomyces vary in their pathology as a result of the location of the organ of fixation. Regardless of its exact location in the host, the organ has a distinct affinity for nervous tissues. It is always located adjacent to a major nerve or its rootlets infiltrate and penetrate a large nerve. The rootlets also penetrate and ramify through the connective tissues, musculature and in some instances, the gonads of the host $(54,59,61,68)$. In some species the rootlets are found a considerable distance from the organ of fixation. The cuticle of the organ of fixation is too thick to allow for the passage of food. The parasite gains nutrition from absorption via the sieve plate and the attached rootlets (61).

Infection by Thalassomyces elicits a chitinous host reaction around the distal portions of the interior organ of fixation, and at the junction of the internal and external body of the parasite $(59,61,68)$. This reaction can cause considerable distortion to the carapace of the host. For T. capillosus, the deformation of the carapace led to some confusion in the taxonomy of the hosts. Pasiphaea principalis Sund, 1913 was described on the basis of consistent deformations of the rostrum and abdomen that were caused by the parasite. The correct identity of its host, $P$. tarda, was diagnosed only after the affect of the parasite was recognized $(128,129)$. Infected $P$. pacifica have a pronounced distortion of the antero-dorsal region of the rostrum (57), and other species of Thalassomyces deform the carapaces of their mysid hosts (54).

With their predilection for the nerves, it seems reasonable to speculate that Thalassomyces spp. may cause significant changes to the behavior of their hosts. The eyestalk-dwelling $T$. californiensis can at times be quite dense, and can infect both eyestalks of its host $P$. emarginata (59, Shields, unpubl. data). Since the parasite may potentially affect the vision of its host, perhaps it affects the ability of the host to undergo vertical migration in the water column. Such an effect could have consequences to the transmission of the parasite. In a similar vein, T. marsupii penetrates into the ventral nerve cord of its host Parathemisto gaudichaudii and protrudes into the marsupium where it resembles the cgg mass. Perhaps the behavior of the host is modified to resemble that of ovigerous females with improved grooming and docility (cf. Sacculina granifera infections in Portunus pelagicus [130]).

As with the parasitic dinoflagellates, infection by Thalassomyces can cause castration. Host castration is not, however, an inevitable outcome of infection. Thalassomyces marsupii and $T$. californiensis do not castrate their hosts (68, Shields, unpubl. data), while $T$. boschma, T. fagei, and $T$. fasciatus partially castrate or only occasionally castrate their hosts $(56,61,66)$.

Hosts castrated by the parasites occasionally exhibit a loss or retardation in the development of secondary sexual characters. This effect, which results in feminization of males and the retention of juvenile characters in females, was first noted by Fage (66) and further substantiated by Einarsson (131) and Boschma (61). The severity of the feminization may be related to the number of parasites on a host (61). Mauchline (63) found that $32 \%$ of $T$. fageiinfected Thysanoessa raschi showed no visible development of secondary sexual characters, i.e. were castrated. Five infected females had, however, mated. None of the infected hosts examined by Hoffman and Yancey (57) possessed secondary sexual characters. In a study of three species of euphausiids, Ramirez and Dato (91) found that $52 \%$ of hosts showed a reduction of sexual characters when infected with $T$. fagei. Complete recovery of the host can occur as a scarred Stilomysis major was found bearing eggs (54).

\section{Epizootiology}

Few studies have examined the host and environmental factors that contribute to the infection dynamics of the Ellobiopsidae. Thalassomyces spp. have received the most attention, again, because of their overt signs of infection. Host sex may be important to the biology of the parasites as $T$. fagei affects males and females differently. Large male and small female hosts are more commonly parasitized, which suggests that the parasite causes a change in the growth rates between sexes (63). The emergence of the trophomeres through the cuticle of the host suggests that the molt cycle plays an important role in the development of the parasite. Nothing is known, however, about how the parasite may affect ecdysis.

Only one study has reported a definitive seasonality in the prevalence of Thalassomyces infections. A spring peak in the prevalence of the trophomeres of $T$. fagei was noted in Kachemak Bay, Alaska (57). A summer-fall peak in prevalence was noted for T. boschmai in Puget Sound, Washington, but the data were inconclusive (58 in 54). 
The recorded geographic distribution of the Ellobiopsidae is scattered throughout the early literature on the family. For a review of the distribution of the family see Boschma (61) and Wing (54). Briefly, the genus Ellobiocystis has a wide distribution having been reported from the Indian Ocean, the North Sea, the Antarctic Ocean, the Pacific Ocean, and the Atlantic Ocean $(42,43,48,54,61$, 132). The genus Ellobiopsis is also widespread having been reported from the Firth of Clyde (Scotland), the Arctic Ocean, the North Sea, the Indian Ocean, the South Atlantic Ocean, the Black Sea, and the Mediterranean Sea $(16,27,47-49,84,132-$ 134). Santhakumari (48) recently reported that larvae of Portunus pelagicus were hosts for E. chattoni. Portunus pelagicus is the only commercially important species infected by an ellobiopsid; it seems likely that the parasite could seriously hinder the development of infected zoeae. Parallobiopsis coutieri and Rhizellobiopsis eupraxiae are not widely distributed having been reported only from the Mediterranean Sea, and the White Sea, respectively $(52,53,127)$. Their distribution is probably much larger. The genus Thalassomyces is cosmopolitan, having been reported from most oceans and many seas of the world $(43,54,61)$.

Epizootics have been reported for Ellobiocystis caridarum (Auke Bay, Alaska), Ellobiopsis chattoni, (Zanzibar Channel, Indian Ocean), Thalassomyces boschmai (Puget Sound, Washington), $T$. californiensis (Santa Barbara Basin, California), $T$. capillosus (Oslofjord, Norway and Puget Sound, Washington), and T. fagei (South Atlantic, North Sea, and Kachemak Bay, Alaska) (Table 2). Epizootics of T. californiensis occur in small patches of infected hosts (59, Shields, unpubl. data). Perhaps changes in host behavior or proximity to infected hosts increases the transmission rate of the parasites resulting in an aggregation of infected individuals in the mesopelagic environment. As infections by ellobiopsids do not necessarily castrate or kill their hosts, these parasites may not have as great an effect on their host populations as that reported for the highly pathogenic Syndinium spp. or Hematodinium perezi.

\section{SUMMARY AND CONCLUSIONS}

\section{Taxonomy}

The systematics and taxonomy of the parasitic dinoflagellates of crustaceans requires further study. Many questions need to be addressed: Are members of the Chytriodinidae correctly placed in the Blastodinida? Are Dissodinium and Syltodinium members of the Chytriodinidae? The members of the Syndinida need better definition. Do the differences between Hematodinium and Syndinium warrant familial separation? How many species of Hematodinium are represented in the disparate host species? The systematic positions of the Paradinida and the Ellobiopsidae need to be established and their possible relationship with the dinoflagellates should be determined. Comparative ultrastructural studies coupled with such new techniques as DNA phylogeny using the polymerase chain reaction ( $\mathrm{PCR}$ ), and small unit RNA base sequence analysis may provide the morphological and genetic clues to resolve these taxonomic issues.

\section{Life cycle}

No complete life cycle has been elucidated for any of the parasitic dinoflagellates of crustaceans. While some of the parasitic dinoflagellates have been cultured over short periods (i.e. Chytriodinium spp., Dissodinium spp.), none has been maintained in the laboratory for extended periods. For most of the species, it is not known whether the dinospore is the transmissive stage or an intermediate stage that precedes a resting cyst or other state. Gamogony and meiosis have only been observed for Paradinium poucheti and possibly Dissodinium pseudolunula $(4,122)$. The following questions need to be addressed. How are the parasites transmitted to their hosts? Is the dinospore stage a short-lived, free-living stage that directly infects its host or does it develop into a long-lived, resting stage that does not directly infect the host? Does gamogony occur in the life cycle, and at what stage? What host and environmental factors facilitate the life cycles of these parasites?

\section{Pathology}

The pathogenicity of the parasitic dinoflagellates varies with their intimacy with their hosts. The gutdwelling blastodinids are relatively benign, while the egg parasitic chytriodinids could be categorized as parasitoids because they kill their hosts. The pervasive Syndinidae and Paradinida are overtly pathogenic and often result in the death of their hosts. Castration and feminization are typical outcomes to infection by the parasites. While all of the parasitic forms can castrate their hosts, the severity of the effect appears dependent upon the invasiveness of the parasitic species. The Ellobiopsidae illustrate this point as castration occurs in some host species but not in others; it may be related to the size of the infected host, the duration and intensity of the parasitic infection and the degree of penetration into the host. How the hosts respond to these parasites is virtually unknown. 


\section{Epizootiology}

Many parasitic dinoflagellates of crustaceans are capable of causing epizootics in their host populations (Table 2). These epizootics can have serious effects on the economics of crustacean fisheries, and may presumably result in fundamental changes to their ecological communities. There are many gaps in our understanding of the factors and conditions that are responsible for outbreaks of diseases in marine environments. Identified factors in the outbreaks of parasitic dinoflagellates are molt condition and sex of the host, salinity, temperature, and water regime. The application of "landscape" ecology, which has proven useful to the study of insect vectors, to the epizootiology of these dinoflagellates, may help uncover the underlying environmental and hydrographic factors that facilitate their transmission. Several marine organisms suffer epizootics from disease agents: e.g. Duboscquella cachoni in Eutintinnus pectinis (135), Labyrinthula sp. on Zostera marina (136), Haplosporidium nelsoni in Crassostrea virginica (137), Carcinonemertes regicides on Paralithodes camtschatica (119), Briarosaccus callosus in Lithodes aequispina (118). Epizootics in these host-parasite systems are associated with unique hydrological features (fjords, estuaries, salinity and temperature regimes, etc.). The occurrence of the epizootics with these hydrological features suggest that a fusion of hydrographic and geographic studies with ecological research will provide a better understanding of the epizootiology of the causative agents.

Several important questions in the epizootiology of the parasitic dinoflagellates need to be addressed: What factors are important to the transmission of the parasites? What is the seasonal pattern of the parasites? How do seasonal shifts in the structure of the host populations affect the dynamics of infection? How does host density influence the epizootiology of the parasites and do epizootics occur in locations with low host densities? What factors contribute to or cause the epizootics of Hematodinium and other parasitic dinoflagellates? How do the different factors and conditions act to effect epizootics in crustaceans? Addressing these difficult questions will no doubt improve our understanding of the epizootiology of these and other marine parasites.

Acknowledgments - I thank Drs. Gene Burreson and Frank Perkins for their critiques. Dr. Gretchen Messick graciously provided an advance copy of her ms. Julie Shields and Bland Crowder assisted with the French translations. Julie Shields, Harold Burrell and Maurice Lynch provided technical assistance. Marilyn Lewis ably obtained numerous references through interlibrary loan. VIMS contribution number 1870 .

\section{REFERENCES}

1. Chatton, É. (1920). Les Péridiniens parasites: morphologie, reproduction, ethologie. Arch. Zool. Exp. Gen. 59: 1-475.

2. Cachon, J. (1964). Contribution a l'etude des Péridiniens parasites. Cytologie, cycles évolutifs. Ann. Sci. Natur., Zool., Paris, Ser. 12, 6: 1-158.

3. Lom, J. (1981). Fish invading dinoflagellates: A synopsis of existing and newly proposed genera. Folia Parasitol., Praha 28: 3-11.

4. Drebes, G. (1984). Life cycle and host specificity of marine parasitic dinophytes. Helgoländer Meeresunters. 37: 603-622.

5. Chatton, É., Poisson, R. (1931). Sur l'existence, dans le sand des Crabes, de Péridiniens parasites: Hematodinium perezi n.g., n.sp. (Syndinidae). C. R. Seances Soc. Biol., Paris 105: 553-557.

6. Cachon, J., Cachon, M. (1987). Parasitic dinoflagellates. In: Taylor, F.J.R. (ed.) The Biology of Dinoflagellates, Blackwell Scientific, Oxford, UK, pp. 571-610.

7. Chatton, É. (1910). Sur l'existence de Dinoflagélles parasites coelomiques. Les Syndinium chez les Copépodes pélagiques. C. R. Hebd. Séanc. Acad. Sci., Paris, Ser. D, 102: 654-656.

8. Taylor, F.J.R. (1987). Taxonomy and classification. In: Taylor, F.J.R. (ed.) The Biology of Dinoflagellates, Blackwell Scientific, Oxford, pp. 723-732.

9. Sournia, A., Cachon, J., Cachon, M. (1975). Catalogue des espèces el laxons infraspécifiques de Dinoflagellés marins actuels publiés depuis la révision de J. Schiller. II. Dinoflagélles parasites ou symbiotiques. Arch. Protistenk, 117: 1-19.

10. Soyer, M.-O. (1969). Rapports existant entre chromosomes et membrane nucléaire chez un Dinoflagellé parasite du genre Blastodinium Chatton. C. R. Hebd. Séanc. Acad. Sci., Paris, Ser. D, 268: 2082-2084.

11. Meyers, T., Koeneman, T.M., Botelho, C., Short, S. (1987). Bitter crab disease: A fatal dinoflagellate infection and marketing problem for Alaskan Tanner crabs Chionoecetes bairdi. Dis. aquat. Orgs. 3: 195216.

12. Field, R.H., Chapman, C.J., Taylor, A.C., Neil, D.M., Vickerman, K. (1992). Infection of the Norway lobster Nephrops norvegicus by a Hematodinium-like species of dinoflagellate on the west coast of Scotland. Dis. aquat. Orgs. 13: 1-15.

13. Ianora, A., Mazzocchi, M.G., Scotto di Carlo, B. (1987). Impact of parasitism and intersexuality on Mediterranean populations of Paracalanus parvus (Copepoda: Calanoida). Dis. aquat. Orgs. 3: 2936.

14. Kimmerer, W.J., McKinnon, A.D. (1990). High mortality in a copepod population caused by a parasitic dinoflagellate. Mar. Biol. 107: 449-452.

15. Sewell, R.B.S. (1951). The epibionts and parasites of the planktonic Copepoda of the Arabian Sea. John Murray Exp., Sci. Rep. Br. Mus. (N.H.) 9: 255-394.

16. Apstein, C. (1911). Parasiten von Calanus finmarchicus. Wissensch. Meeresunters., Abt. Kiel, Ser. N.F., 13: 205-223.

17. Ianora, A., Scotto di Carlo, B., Mazzocchi, M.G., Mascellaro, P. (1990). Histomorphological changes 
in the reproductive condition of parasitized marine planktonic copepods. J. Plankt. Res. 12: 249-258.

18. Dogiel, V. (1906). Beiträge zur Kenntnis der Peridineen. Mitt. Zool. Stn. Neapel 18(1): 1-45.

19. Cachon, J., Cachon, M. (1968). Cytologie et cycle évolutif des Chytriodinium (Chatton). Protistologica 4: 249-262.

20. Gönnert, R. (1936). Sporodinium pseudocalani n.g., n. sp., ein Parasit auf Copepodeneiern. Z. Parasitenk. 9: 140-143.

21. Drcbes, G. (1978). Dissodinium pseudolunula (Dinophyta), a parasite on copepod eggs. Br. Phycol. J. 13: 319-327.

22. Elbrächter, M. (1988). Life cycle of Schizochytriodinium calani nov. gen. nov. spec., a dinoflagellate parasitizing copepod eggs. Helgoländer Meeresunters. 42: $593-599$.

23. Drebes, G. (1988). Syltodinium listii gen. et spec. nov., a marine ectoparasitic dinoflagellate on eggs of copepods and rotifers. Helgoländer Meeresunters. 42: 583-591.

24. Chatton, É., Hovasse, H. (1938). Actinodinium apsteini n. g., n. sp. Péridinien parasite entérocoelomique des Acartia (Copćpodes). Arch. Zool. Exp. Gen. 79: 24-29.

25. Chatton, É. (1952). Classe des Dinoflagelles ou Péridiniens. In: Grassé, P.-P. (ed.) Traité de Zoologie, Vol. 1. Masson et Cie, Paris, pp. 309-390.

26. Manier, J.-F., Fize, A., Grizel, H. (1971). Syndinium gammari n. sp. péridinien Dubosquodinida Syndinidae, parasite de Gammarus locusta (Lin.) Crustacé Amphipode. Protistologica 7: 213-219.

27. Jepps, M.W. (1937). On the protozoan parasites of Calanus finmarchicus in the Clyde Sea area. Quart. J. Microsc. Sci. 79: 589-658.

28. Stickney, A.P. (1978). A previously unreported peridinian parasite in the eggs of the northern shrimp, Pandalus borealis. J. Invert. Pathol. 32: 212-215.

29. Latrouite, D., Morizur, Y., Noël, P., Chagot, D., Wilhelm, G. (1988). Mortalite du torteau Cancer pagurus provoquee par le dinoflagelle parasite: $\mathrm{He}$ matodinium sp. Con. Int. Expl. Mer, Ser. CM, K: 32(E): $1-10$.

30. Wilhelm, G., Boulo, V. (1988). Infection de l'etrille Liocarcinus puber (L.) par un dinoflagelle parasite de type Hematodinium sp. Con. Int. Expl. Mer, Ser. CM, K: 32(O): 1-9.

31. MacLean, S.A., Ruddell, C.L. (1978). Three new crustacean hosts for the parasitic dinoflagellate Hematodinium perezi (Dinoflagellata: Syndinidae). J. Parasitol. 64: 158-160.

32. Newman, M.W., Johnson, C.A. (1975). A disease of blue crabs (Callinectes sapidus) caused by a parasitic dinoflagellate, Hematodinium sp. J. Parasitol. 63: 554-557.

33. Shields, J.D. (1992). The parasites and symbionts of the blue sand crab, Portunus pelagicus, from Moreton Bay, Australia. J. Crustacean Biol. 12: 94-100.

34. Hudson, D. A., Shields, J.D. Hematodinium australis, $\mathrm{n}$. sp., a parasitic dinoflagellate of the sand crab, Portunus pelagicus, and the mud crab, Scylla serrata, from Moreton Bay, Australia. Dis. aquat. Orgs. (in press).

35. Hudson, D.A., Hudson, N.B., Shields, J.D. (1992). Infection of Trapezia spp. (Decapoda: Xanthidae) by
Hematodinium sp. (Duboscquodinida: Syndinidae): a new family record of infection. J. Fish Dis. 16: 273-276.

36. Meyers, T., Botelho, C., Koeneman, T.M., Short, S., Imamura, K. (1990). Distribution of bitter crab dinoflagellate syndrome in southeast Alaskan Tanner crabs Chionoecetes bairdi. Dis. aquat. Orgs. 9: 37-43.

37. Johnson, P.T. (1986). Parasites of benthic amphipods: Dinoflagellates (Duboscquodinida: Syndinidae). Fish. Bull. 84: 605-614.

38. Bower, S.M., Meyer, G.R., Buutillier, J.A. (1993). Diseases of spot prawns Pandalus platyceros caused by an intracellular bacterium and a Hematodiniumlike Protozoa. J. Shellfish Res. 12: 135.

39. Meyers, T., Lightner, D.V., Redman, R.M. (1994). A dinoflagellate-like parasite in Alaskan spot shrimp Pandalus platyceros and pink shrimp P. borealis. Dis. aquat. Orgs. 18: 71-76.

40. Chatton, É., Soyer, M.-O. (1973). Le cycle évolutif du Paradinium poucheti Chatton, flagellé parasite plasmodial des Copépodes. Les Paradinides. Ann. Sci. Natur., Zool., Paris, Ser. 12, 15: 27-60.

41. Cachon, J., Cachon, M., Pyne, C.K. (1968). Structure et ultrastructure de Paradinium poucheti Chatton 1910, et position systématique des Paradinides. Protistologica 4: 303-311.

42. Coutière, H. (1911). Sur les Ellobiopsis des crevettes bathypélagiques. C. R. Hebd. Séanc. Acad. Sci., Paris, Ser. D, 152: 409-411.

43. Boschma, H. (1959). Ellobiopsidae from tropical West Africa. Atlantide Report 5: 145-175.

44. Steuer, A. (1928). Über Ellobiopsis chattoni Caullery 1910, einen ectoparasitischen Flagellaten mariner Copepoden. Arch. Protistenk. 60: 501-510.

45. Marshall, S.M., Nicholls, A.G., Orr, A.P. (1934). On the biology of Calanus finmarchicus. V. Seasonal distribution, size, weight and chemical composition in Loch Striven in 1933 and their relation to the phytoplankton. J. Mar. Biol. Assoc. UK 19: 793-819.

46. Caullery, M. (1910). Ellobiopsis chattoni n.g., n.sp. parasite de Calanus helgolandicus Claus, appartenant probablement aux Péridiniens. Bull. Scient. France Belgique 44: 201-214.

47. Willey, A. (1920). Report on the marine Copepoda collected during the Canadian Arctic Expedition. Rep. Can. Arctic. Exp. 7(k): 1-46.

48. Santhakumari, V. (1986). Epizoic and ectoparasitic protozoans from crab larvae. Mahasagar 19: 65-67.

49. Steuer, A. (1932). Über Ellobiopsis elongata n. sp. aus dem Südatlantik. Note Inst. ital.-germ. Biol. Mar. Rovigno d'Istria(5): 1-6.

50. Santhakumari, V., Saraswathy, M. (1979). On the Ellobiopsidae, parasitic Protozoa, from zooplankton. Mahasagar 12: 83-92.

51. Hovasse, R. (1951). Ellobiopsis fagei Hovasse, Ellobiopsidé parasite, en Méditerranée, de Clausocalanus arcuicornis Dana. Bull. Inst. Océan.(1016): 1-12.

52. Collin, B. (1913). Sur un Ellobiopsidé nouveau, parasite des Nébalies (Parallobiopsis coutieri n.g., n.sp.). C. R. Hebd. Séanc. Acad. Sci., Paris, Ser. D, 156: 1332-1333.

53. Zachs, I. (1923). Sur un nouveau Ellobiopsidéparasite du Nephtys ciliata Müll. Ellobiopsis (?) expraxiae n. sp. Trav. Soc. Natural. Petrograd. 53: $175-176$.

54. Wing, B.L. (1975). New records of Ellobiopsidae 
(Protista (Incertae sedis)) from the North Pacific with a description of Thalassomyces albatrossi n.sp., a parasite of the mysid Stilomysis major. Fish. Bull. 73: 169-185.

55. Nouvel, H. (1954). Un Ellobiopsidae nouveau (Amallocystis boschmai n. sp.) parasite d'un Mysidacé en Méditerranée. Vie Milieu 4: 57-58.

56. Nouvel, H., Hoenigman, J. (1955). Amallocystis boschmai Nouvel, 1954 Ellobiopsidé parasite du Mysidacé Leptomysis gracilis G.O. Sars. Vie Milieu, Scr. Résultats de Campagnes duc Pr. LacazeDuthiers, Vol. 2, 6: 7-19.

57. Hoffman, E.G., Yancey, R.M. (1966). Ellobiopsidae of Alaskan coastal waters. Pac. Sci. 20: 70-78.

58. Thorne, R.E. 1968. Diel variations in distributions and feeding behavior of Mysidacea in Puget Sound. Master's Thesis, Univ. Washington, Seattle, $49 \mathrm{pp}$.

59. Collard, S.B. (1964). Thalassomyces californiensis sp. n., a parasite of the nervous system of a shrimp, Pasiphaea emarginata Rathbun. Proc. Biol. Med. Sci. (Konink. Neder. Akad. Wetten.), Ser. C, 69(1): 37-49.

60. Fage, L. (1938). A propos d'un nouvel Ellobiopsidé Amallocystis capillosus n. sp. parasite de Pasiphaea tarda Kröyer (Crust. Decap.). Trav. Sta. Zool. Wimereux 13: 287-291.

61. Boschma, H. (1949). Ellobiopsidae. Discovery Reports 25: 281-314.

62. MacDonald, R. (1927). Food and habits of Meganyctiphanes norvegica. J. Mar. Biol. Assoc. UK 14: 753784.

63. Mauchline, J. (1966). Thalassomyces fagei, an ellobiopsid parasite of the euphausiid crustacean, Thysanuessa raschi. J. Mar. Biol. Assoc. UK 46: 531-539.

64. Komaki, Y. (1970). On the parasitic organisms in a krill, Euphousia similis, from Suruga Bay. J. Ocean. Soc. Japan. 26: 283-295.

65. Vader, W. (1973). A bibliography of the Ellobiopsidae, 1959-1971, with a list of Thalassomyces species and their hosts. Sarsia 52: 175-180.

66. Fage, L. (1936). Sur un Ellobiopsidé nouveau Amallocystis capillosus gen. et sp. nov. parasite des Mysidacés bathypélagiques. Arch. Zool. Exp. Gen. 78: 145-154.

67. Fage, L. (1941). Mysidacea. Lophogastridae I. Dana Report, Carlsberg Foundation 19: 1-52.

68. Kane, J.E. (1964). Thalassomyces marsupii, a mew species of ellobiopsid parasite on the hyperiid amphipod Parathemisto gaudchaudii (Guér.). NZ J. Sci. 7: 289-303

69. Vader, W., Kane, J.E. (1968). New hosts and distribution records of Thalassomyces marsupii Kane, an ellobiopsid parasite on amphipods. Sarsia 33: 13-20.

70. Tencati, J.R., Geiger, S.R. (1968). Pelagic amphipods of the slope waters of northeast Greenland. J. Fish. Res. Bd. Can. 25: 1637-1650.

71. Galt, J.H., Whisler, H.C. (1970). Differentiation of flagellated spores in Thalassomyces ellobiopsid parasite of marine Crustacea. Arch. Mikrobiol. 71: 295-303.

72. Hoenigman, J. (1960). Faits nouveaux concernant les Mysidaces (Crustacea) et leurs epibiontes dans l'Adriatique. Rapp. P.-V. Réun. Comm. Int. Explor. Sci. Mer Méditerr. 17: 603-616.

73. Hoenigman, J. (1954). Novosti s Podrocja Jadran- skega Zooplanktona. (O najdbi elobiopsidov). Bioloski Vestnik, Ljubljana 3: 106-116.

74. Wasmer, R.A. (1986). New records of parasitic Thalassomyces species (Ellobiopsidae) from oplophorid shrimps in the South Pacific. Crustaceana 50: 312-318.

75. Niezabitowski, E.L. (1913). Pasorzyty roslinne morskich raków glebinowych z rodzaju Pasiphaea. Kosmos, Lwow 38: 1563-1572.

76. Chatton, É. (1906). Les Blastodinides, ordre nouveau de Dinoflagellćs parasites. C. R. Hebd. Séanc. Acad. Sci., Paris 143: 981-983.

77. Chatton, É. (1929). Différenciation et isolement géographique d'une espèce (Blastodinium hyalinum Ch.) par substitution partielle des conditions oecologiques (parasitisme hétértrophe) aux conditions cosmiques (autotrophisme) de son existence. Arch. Zool. Exp. Gen. 68: 1-7.

78. Chatton, É. (1908). Note préliminaire sur trois formes nouvelles du genre Blastodinium Chatton. Bull. Soc. Zool. France 33: 134-137.

79. Grell, K.G. 1973. Protozoology, Springer-Verlag, NY, $554 \mathrm{pp}$.

80. Pasternak, A.F., Arashkevich, Y.G., Sorokin, Y.S. (1984). The role of parasitic algal genus Blastodinium in the ecology of planktic copepods. Oceanology 24 : 748-751.

81. Humphrey, G.F. (1975). The photosynthesis:respiration ratio of some unicellular marine algae. J. Exp. Mar. Biol. Ecol 18: 111-119.

82. Reinhard, E.G. (1956). Parasitic castration of Crustacea. Exp. Parasitol. 5: 79-107.

83. Giard, A. (1887). Parasitic castration and its influence upon the external characters of the male sex, in the decapod Crustacea. Ann. Mag. Nat. Hist., Ser. 5th, 19: 325-345.

84. Cattley, J.G. (1948). Scx reversal in copepods. Nature 161: 937 .

85. Shields, J.D., Wood, F.E.I. (1993). The impact of parasites on the reproduction and fecundity of the blue sand crab Portunus pelagicus from Moreton Bay, Australia. Mar. Ecol. Prog. Ser. 92: 159-170.

86. Kofoid, C.A. (1931). Report on the biological survey of Mutsu Bay. 18. Protozoan fauna of Mustu Bay. Subclass Dinoflagellata; Tribe Gymnodinoidae, Fac. Sci. Rep. Tohoku Imp. Univ. 4th Ser., Biology 6: 1-43.

87. Vane, F.R. (1952). The distribution of Blastodinium hyalinum in the North Sea. Challenger Soc. 3: 23-24.

88. Messick, G. A. Hematodinium perezi infections in adult and juvenile blue crabs Callinectes sapidus from coastal bays of Maryland and Virginia, USA. Dis. aquat. Org. (In press).

89. Hudson, D.A., Lester, R.J.G. A parasitological survey of the mud crab Scylla serrata (Forskál) from southern Moreton Bay, Queensland, Australia. Aquaculture. (In press).

90. Wickstead, J.H. (1963). A new record of Ellobiopsis chattoni (Flagellata incertae sedis) and its incidence in a population of Undinula vulgarus var. major (Crustacea Copepoda). Parasitology 53: 293-296.

91. Ramírez, F.C., Dato, C. (1989). Observations on parasitism by Thalassomyces fagei on three euphausiid species in Southern Atlantic waters. Oceanol. Acta 12: 95-97.

92. Smith, J.W. (1981). The occurrence of Thalassomyces 
fagei (Ellobiopsidae) in euphausiids (Crustacea: Malacostraca) in the north-east Atlantic and northern North Sea. J. Mar. Biol. Assoc. UK, 61: 995999.

93. Chatton, É. (1912). Diagnoses préliminaires de Péridiniens parasites nouveaux. Bull. Soc. Zool. France 37: 85-93.

94. Elbrächter, M., Drebes, G. (1978). Life cycles, phylogeny and taxonomy of Dissodinium and Pyrocystis (Dinophyta). Helgoländer Meeresunters. 31: 347-366.

95. Stosch, H.A., von. (1973). Observations on vegetative repoduction and sexual life cycles of two freshwater dinoflagellates, Gymnodinium pseudopalustre Schiller and Woloszynskia apiculata sp. nov. $\mathrm{Br}$. Phycol. J. 8: 105-134.

96. Drebes, G. (1981). Possible resting spores of Dissodinium pseudolunula (Dinophyta) and their relation to other taxa. Br. Phycol. J. 16: 207-215.

97. John, A.W.G., Reid, P.C. (1983). Possible resting cysts of Dissodinium pseudolunula Swift ex Elbrächter et Drebes in the Northeast Atlantic and the North Sea. Br. Phycol. J. 18: 61-67.

98. Kofoid, C.A., Swezy, O. (1921). The free-living unarmored Dinoflagellata. Mem. Univ. Calif. 5: 1-562.

99. Gaines, G., Elbrächter, M. (1987). Heterotrophic nutrition. In: Taylor, F.J.R. (ed.) The Biology of Dinoflagellates, Blackwell Scientific, Oxford, UK, pp. 224-268.

100. Kuris, A.M. (1991). A review of patterns and causes of crustacean brood mortality. In: Wenner, A., Kuris, A.M. (eds.) Crustacean Issues, Vol. 7, Crustacean Egg Production. A. A. Balkema, Rotterdam, pp. 117-141.

101. Wickham, D.E. (1986). Epizootic infestations by nemertean brood parasites on commercially important crustaceans. Can. J. Fish. Aquat. Sci, 43: 2295-2302.

102. Coats, D.W. (1988). Duboscquella cachoni n.sp., a parasitic dinoflagellate lethal to its tintinnine host Eutintinnus pectinis. J. Protozool. 35: 607-617.

103. Eaton, W.D., Love, D.C., Botelho, C., Meyers, T.R., Imamura, K., Koeneman, T. (1991). Preliminary results on the seasonality and life cycle of the parasitic dinoflagellate causing bitter crab disease in Alaskan tanner crabs Chionoexetes bairdi. J. Invert. Pathol. 57: 426-434.

104. Chatton, É. (1921). Sur un mécanisme cinétique nouveau: La mitose syndinienne chez les Peridiniens parasites plasmodiaux. C. R. Hebd. Séanc. Acad. Sci., Paris, Ser. D, 173: 859-862.

105. Hollande, A. (1974). Étude comparée de la mitose syndinienne et de celle des péridiniens libres et des Hypermastigines infrastructure et cycle évolutif des Syndinides parasites de Radiolaires. Protistologica 10: 413-451.

106. Ris, H., Kubai, D.F. (1974). An unusual mitotic mechanism in the parasitic protozoan Syndinium sp. J. Cell Biol. 60: 701-720.

107. Soyer, M,-O. (1974). Étude ultrastructurale de Syndinium sp. Chatton parasite de copépodes pélagiques. Vie Milieu, Ser. A, 24: 191-212.

108. Marshall, S.M., Orr, A.P. (1955). The biology of a marine copepod Calanus finmarchicus (Gunnerus). Oliver \& Boyd, Edinburgh, 188 pp.

109. Fleminger, A. (1985). Dimorphism and possible sex change in copepods of the family Calanidae. Mar. Biol. 88: 273-294.

110. Elian, L. (1970). Syndinium turbo Chatton (Dinoflagelat) parazit la copepodele marine. Hidrobiologia 11: 193-195.

111. Overstreet, R.M. (1978). Marine maladies? Worms, germs, and other symbionts from the Northern Gulf of Mexico, MASGP-78-021. Mississippi-Alabama Sea Grant Consortium, Ocean Springs, Miss. 150 pp.

112. Couch, J.A. (1983). Diseases caused by Protozoa. In: Provenzano, A.J., Jr. (ed.) The Biology of the Crustacea, Vol. 6, Pathobiology. Academic Press, New York, pp. 79-111.

113. Van Engel, W.A. (1958). The blue crab and its fishery in Chesapeake Bay. I. Reproduction, early development, growth and migration. Comm. Fish. Rev. 20: 6-17.

114. Tagatz, M.E. (1968). Biology of the blue crab, $\mathrm{Cal}$ linectes sapidus Rathbun, in the St. John's River, Florida. Fish. Bull. 67: 17-32.

115. Virnstein, R.W. (1977). The importance of predation by crabs and fishes on benthic infauna in Chesapeake Bay. Ecology 58: 1199-1217.

116. Hines, A.H., Lipcius, R.N., Haddon, A.M. (1987). Population dynamics and habitat partitioning by size, sex, and molt stage of blue crabs Callinectes sapidus in a subestuary of central Chesapeake Bay. Mar. Ecol. Prog. Ser. 36: 55-64.

117. Hines, A.H., Haddon, A.M., Wiechert, L.A. (1990). Guild structure and foraging impact of blue crabs and epibenthic fish in a subestuary of Chesapeake Bay. Mar. Ecol. Prog. Ser. 67: 105-126.

118. Sloan, N.A. (1984). Incidence and effects of parasitism by the rhizocephalan barnacle, Briarosaccus callosus Boschma, in the golden king crab, Lithodes aequispina Benedict, from deep fjords in northern British Columbia, Canada. J. Exp. Mar. Biol. Ecol 84: 111-131.

119. Kuris, A.M., Blau, S.F., Paul, A.J., Shields, J.D., Wickham, D.E. (1991). Infestation by brood symbionts and their impact on egg mortality of the red king crab, Paralithodes camtschatica, in Alaska: geographic and temporal variation. Can. J. Fish. Aquat. Sci. 48: 559-568.

120. Sloan, N.A. (1985). Life history characteristics of fjord-dwelling golden king crabs Lithodes aequispina. Mar. Ecol. Prog. Ser. 22: 219-228.

121. Kuris, A.M., Lafferty, K.D. (1992). Modelling crustacean fisheries: Affects of parasites on management strategies. Can. J. Fish. Aquat. Sci. 49: 327-336.

122. Chatton, É. (1927). La gamétogenèse méiotique du Flagellé Paradinium poucheti. C. R. Hebd. Séanc. Acad. Sci., Paris, Ser. d, 185: 400-403.

123. Grassé, P.-P. (1952). Incertae sedis-Paradinium poucheti Chatton. In: Grassé, P.-P. (ed.) Traité de Zoologie, Vol. 1. Masson et Cie, Paris, pp. 305-306.

124. Chatton, É. (1910). Paradinium poucheti n. g., n. sp., Flagellé parasite d'Acartia clausi (Copépode pélagique). C. R. Seances Soc. Biol., Paris 68: 342344.

125. Hovasse, R. (1925). Les Ellobiopsidés se propagent par flagellispores. C. R. Hebd. Séanc. Acad. Sci., Paris, Ser. D, 181: 196.

126. Grassé, P.-P. (1952). Les Ellobiopsidae. In: Grassé, P.-P. (ed.) Traité de Zoologie, Vol. 1. Masson et Cie, Paris, pp. 1023-1030. 
127. Hovasse, R. (1926). "Parallobiopsis coutieri" Collin. Morphologie, cytologie, évolution, affinités des Ellobiopsidés. Bull. Biol. France Belgique 60: 409-446.

128. Sund, O. (1913). The glass shrimps (Pasiphaea) in northern waters. Bergens Mus. Årb. 1912(6): 1-18.

129. Sivertsen, E., Holthuis, L.B. (1956). Crustacea Decapoda (the Penaeidea and Stenopodidea excepted). Rep. Scient. Res., Michael Sars N. Atlant. Deep Sea Exped., 1910 5(12): 1-54.

130. Bishop, R.K., Cannon, L.R.G. (1979). Morbid behaviour of the commercial sand crab, Portunus pelagicus (L.), parasitized by Sacculina granifera Boschma, 1973 (Cirripedia: Rhizocephala). J. Fish Dis. 2: 131-144.

131. Einarsson, H. (1945). Euphausiacea I. Northern Atlantic species. Dana Rep. 27 (Carlsberg Foundation Oceanographic Expedition): 1-185.

132. Santhakumari, V. (1985). Distribution of Ellobiop- sidae, parasitic protozoa, in Indian Ocean. Mahasagar 18: $517-520$

133. Mrázek, A. (1902). Arktische Copepoden. In: Römer, F., Schaudinn, F. (eds.) Fauna Arctica, 2: 499-523.

134. Elian, L., Petran, A. (1971). Sur la présence d'Ellobiopsis chattoni Caullery, sur quelques Copépodes de la mer Noire. Rapp. P.-V. Réun. Comm. Int. Explor. Scient. Mer Méditerr. 20: 413-414.

135. Coats, D.W., Heisler, J.J. (1989). Spatial and temporal occurrence of the parasitic dinoflagellate Duboscquella cachoni and its tintinnine host Eutirttinnus pectinis in Chesapeake Bay. Mar. Biol. 101: 401-409.

136. Short, F.T., Muehlstein, L.K., Porter, D. (1987). Eelgrass wasting disease: cause and recurrence of a marine epidemic. Biol. Bull. 173: 557-562.

137. Andrews, J.D. (1966). Oyster mortality studies in Virginia. V. Epizootiology of MSX, protistan pathogen of oysters. Ecology 47: 19-31. 